\title{
Environment, Business, and Health Care Prevail: A Comprehensive, Systematic Review of System Dynamics Application Domains
}

\author{
Marek Zanker, Vladimír Bureš * (D) and Petr Tučník
}

Faculty of Informatics and Management, University of Hradec Kralove, Rokitanskeho 62, 50003 Hradec Kralove, Czech Republic; marek.zanker@uhk.cz (M.Z.); petr.tucnik@uhk.cz (P.T.)

* Correspondence: vladimir.bures@uhk.cz

Citation: Zanker, M.; Bureš, V.; Tučník, P. Environment, Business, and Health Care Prevail: A Comprehensive, Systematic Review of System Dynamics Application Domains. Systems 2021, 9, 28 . https://doi.org/10.3390/ systems 9020028

Academic Editor: Oz Sahin

Received: 6 April 2021

Accepted: 20 April 2021

Published: 21 April 2021

Publisher's Note: MDPI stays neutral with regard to jurisdictional claims in published maps and institutional affiliations.

Copyright: (c) 2021 by the authors. Licensee MDPI, Basel, Switzerland. This article is an open access article distributed under the terms and conditions of the Creative Commons Attribution (CC BY) license (https:// creativecommons.org/licenses/by/ $4.0 /)$.

\begin{abstract}
System dynamics, as a methodology for analyzing and understanding various types of systems, has been applied in research for several decades. We undertook a review to identify the latest application domains and map the realm of system dynamics. The systematic review was conducted according to the PRISMA methodology. We analyzed and categorized 212 articles and found that the vast majority of studies belong to the fields of business administration, health, and environmental research. Altogether, 20 groups of modeling and simulation topics can be recognized. System dynamics is occasionally supported by other modeling methodologies such as the agentbased modeling approach. There are issues related to published studies mostly associated with testing of validity and reasonability of models, leading to the development of predictions that are not grounded in verified models. This study contributes to the development of system dynamics as a methodology that can offer new ideas, highlight limitations, or provide analogies for further research in various research disciplines.
\end{abstract}

Keywords: system dynamics; systematic review; environment; health; business; causal-loop diagram; stock-and-flow diagram; testing

\section{Introduction}

System dynamics represents a specific and original methodological approach to the modeling and simulation of various types of systems. The core concepts of systems thinking, such as interconnectedness, feedbacks, adaptive capacity/resilience, self-organization, and emergence [1], are applied in system dynamics with the intention to help people make better decisions when confronted with complex, dynamic systems. The field provides a philosophy and tools to model and analyze dynamic systems. Equally important, the field provides techniques and tools to investigate current decision-making and to help decisionmakers to learn. In comparison to differential and difference equations traditionally used for the representation of dynamic systems, the modeling language of systems dynamics is intuitive, and it is common for all kinds of applications, such as in medicine, economics, and management. This makes system dynamics an ideal tool for multidisciplinary work, and it makes learning more efficient because basic system structures tend to repeat themselves from one field of application to another. There are two types of diagrams used in system dynamics. While causal-loop diagrams are used for qualitative modeling, stock-and-flow diagrams are applied in quantitative modeling that leads to the development of models that can be consequently simulated and analyzed. Details related to the notations of both diagrams, their components, applied logic, and both strong and weak points can be found in the relevant literature [2]. The system dynamics (SD) domain has seen a significant increase in numbers of applications of SD methods and models in various areas. Since $\mathrm{SD}$ is a well-established methodological approach of modeling and simulation, the range of areas for potential research is gradually increasing, and some of these topics, such as 
water management, the farming industry, and sustainability are currently being prioritized globally. As to date the literature does not include a comprehensive analysis of domains in which SD has been applied as a methodological approach, the main objective of this systematic review is to provide insight into the overall context of SD as an approach for modeling and simulation of various issues. This can help to understand when SD can be chosen as a modeling alternative, identify gaps in application areas, and suggest further steps to make progress in this manner. This systematic review provides a comprehensive overview of contemporary research and shows major application domains. The attention was focused on topical research studies, providing transparent overview of current research trends in the domain of SD. The review also provides pointers toward potential future research areas. It is shown that possible applications lie in a wide selection of domains.

This paper is structured as follows. Section 2 describes the systematic review of major application domains in SD, divided into 20 subcategories. Section 3 presents discussion about various types of SD models. The next section describes methodological details and results of the application of the Preferred Reporting Items for Systematic reviews and Meta-Analyses (PRISMA) methodology, and the final section concludes the paper.

\section{Materials and Methods}

The first step of the review was the acquisition of a data set that could be used for further analysis. In fact, two approaches can be used. The first approach is based on searching for relevant information resources in databases provided by single publishing houses (Elsevier, Springer, Wiley, etc.). The second approach takes advantage of databases in which selected journals are indexed. Both approaches have their own strong and weak points. For instance, the former provides a more comprehensive data set, while the latter works with journals in which quality is acknowledged by an authority and a community. We found the latter more suitable for the purpose of this study due to the absence of redundant records (see Figure 1 with the PRISMA flowchart). Thus, a search in the Scopus database for published papers was conducted. The object of the search was the concept of SD and its applications in various domains. The main eligibility criteria were English language (i.e., readability and understandability at the global scale); year of publication between 2016 and 2019 (an arbitrary choice intending to highlight recent topics; the search for papers took place during the second half of 2020 and thus 2020 records were considered as incomplete for a yearlong analysis); full-text availability (in order to conduct the content analysis); and usage of SD as a specific methodology Especially due to the last criterion, the search query was intricate, as specific methods for modeling dynamics in engineering and the natural sciences had to be excluded. For instance, the query returned papers dealing with multibody system dynamics in astronomy, modeling of fluid dynamics in hydrodynamics, power system dynamics in the energy industry, and control system dynamics. It is apparent that these and similar fields of research both use different methods and apply different tools, and the concept of SD is formulated in a different methodological context. Eventually, papers from the following Scopus domains were included: environmental science, business, social sciences, decision sciences, economics, medicine, agriculture and the biological sciences, psychology, multidisciplinary studies, health, and nursing. 


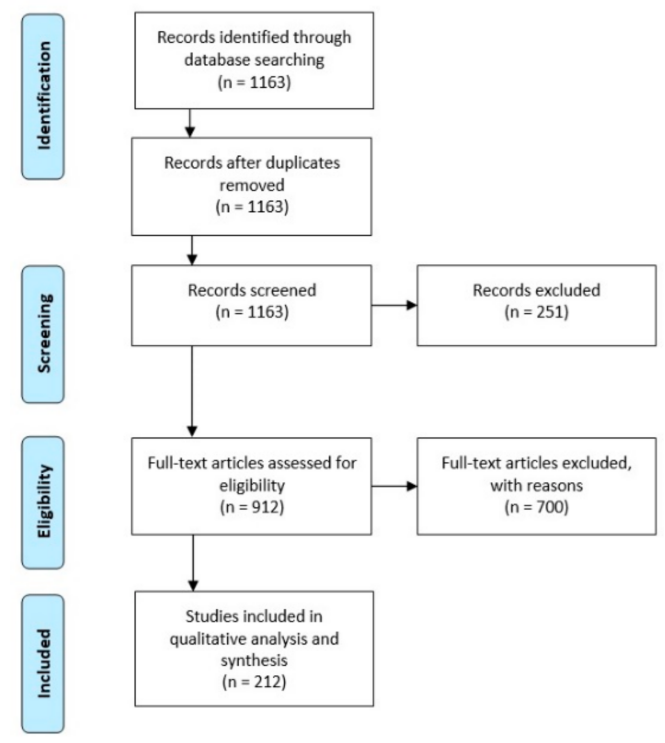

Figure 1. PRISMA flowchart [3].

We identified 1163 papers, of which 912 were selected for full-text screening. Altogether, 212 papers passed the full-text screening.

Grounded in PRISMA results, two types of analyses were conducted-quantitative and the content analysis. The former was based on both the conceptual network analysis of keywords and nouns conducted via VOSviewer, and multidimensional scaling, cooccurrence network, correspondence analysis and the hierarchical clustering conducted in KHCoder. As abstracts contain concepts that are not suitable for text analysis, these had to be excluded. Their list is provided in Table 1. To achieve a trade-off between comprehensibility and complexity of the diagram, all keywords with a minimum number of occurrences equal to nine were included in the developed network presented in Figure 2 (VOSviewer). Parametrization of methods applied in KHCoder are presented in Table 2. These details are provided due to potential replication of the analysis and further technical details are not explained. For instance, in the multidimensional scaling, the Kruskal method is considered to be a standard. However, if Kruskal creates a map too difficult to read, the Sammon method can be considered as an alternative as it tries to keep the distances between words from getting crowded. Furthermore, the Jaccard method is used for reckoning distance between words in sparse data. The Jaccard coefficient emphasizes whether or not specific words co-occur. If documents are long and contain many words, other options such as Euclidean distance or Cosine coefficient are at hand. Curious readers can search for methods' features in relevant information resources.

Table 1. Nouns excluded from text mining.

\begin{tabular}{ccc}
\hline & \multicolumn{3}{c}{ Type of Word } \\
\hline Research-related & SD-related & General concepts without domain associations \\
\hline & & Examples \\
\hline Methodology & Diagram & Process \\
Introduction & Dynamics & Number \\
Discussion & Loop & Year \\
Paper & Feedback & Work \\
Purpose & Behavior & Approach \\
Objective & Variable & Problem \\
Literature & Loop & Research \\
\hline
\end{tabular}




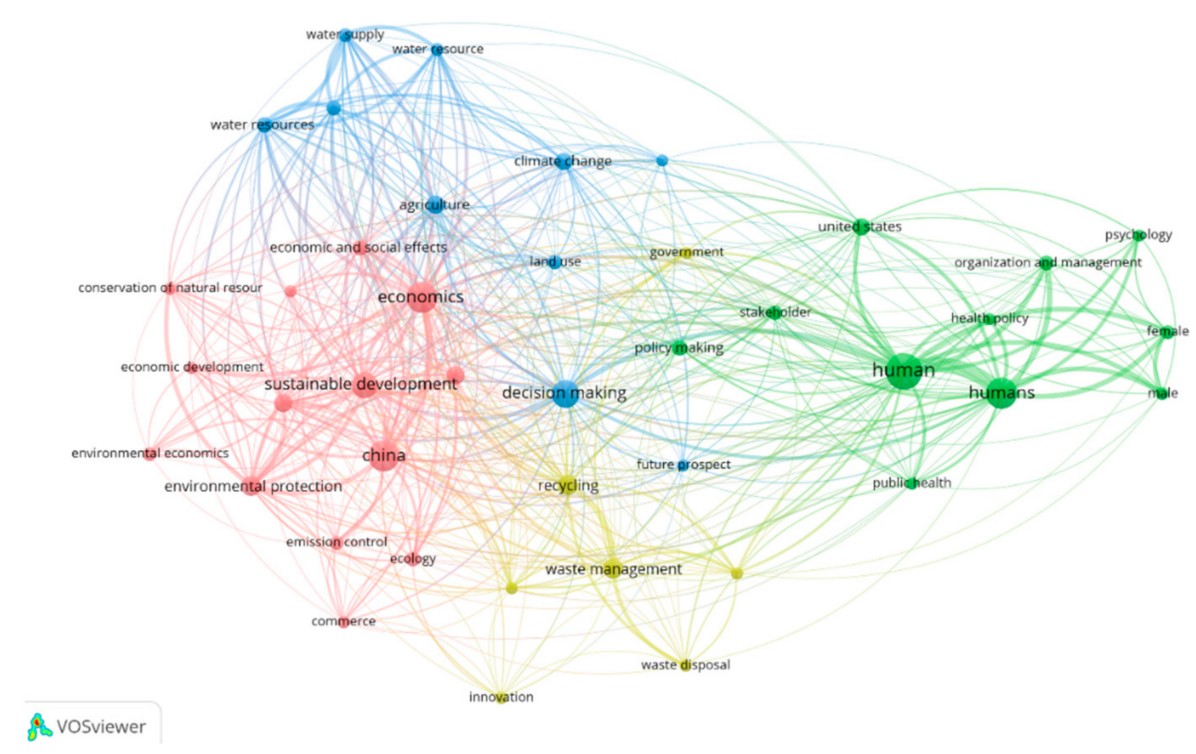

Figure 2. Conceptual network.

Table 2. Settings of applied text-mining tools.

\begin{tabular}{|c|c|c|c|c|}
\hline Tool & Terms' Frequency & Method & Distance Calculation & Specifics \\
\hline Multidimensional scaling & 70-90-110 & $\begin{array}{l}\text { Kruskal, Sammon, } \\
\text { Classical }\end{array}$ & $\begin{array}{l}\text { Jaccard, Cossine, } \\
\text { Euclide }\end{array}$ & Number of clusters: 6-8-10 \\
\hline Co-occurrence network & $50-70-90$ & $\mathrm{~N} / \mathrm{A}$ & $\begin{array}{l}\text { Jaccard, Cossine, } \\
\text { Euclide }\end{array}$ & $\begin{array}{l}\text { Minimum spanning tree only } \\
\text { edges with coefficient } \geq 0.15\end{array}$ \\
\hline Correspondence analysis & 70-90-110 & $\mathrm{N} / \mathrm{A}$ & $\mathrm{N} / \mathrm{A}$ & $\begin{array}{l}\text { Words filtered by chi-square } \\
\text { value: top } 40-60-80\end{array}$ \\
\hline Hierarchical clustering & 70-90-110 & $\begin{array}{l}\text { Ward Average } \\
\text { Complete }\end{array}$ & $\begin{array}{l}\text { Jaccard, Cossine, } \\
\text { Euclide }\end{array}$ & Number of clusters: 6-8-10 \\
\hline
\end{tabular}

\section{Results and Discussion}

The outcomes in Figures 2 and 3 indicate that three basic clusters can be identified. First, a considerable number of studies belong to a group focusing on environmental issues and nature-related topics such as water usage or waste management. Due to its size, this cluster needs further detailed structuring into new independent groups or subclusters during the further analysis. Second, papers dealing with various topics from business and the economy are identified. Third, health-oriented papers represent another cluster, in which topics such as specific diseases or public health-care systems or policies are analyzed.

The content analysis of texts confirms results from the quantitative analysis, as it reveals that the articles could be clustered into several different categories. However, developed groups are an oversimplification of complex structures, as articles may belong to several groups. Table 3 presents identified topic groups with associated subgroups and Table 4 introduces characteristics of all analyzed studies. 


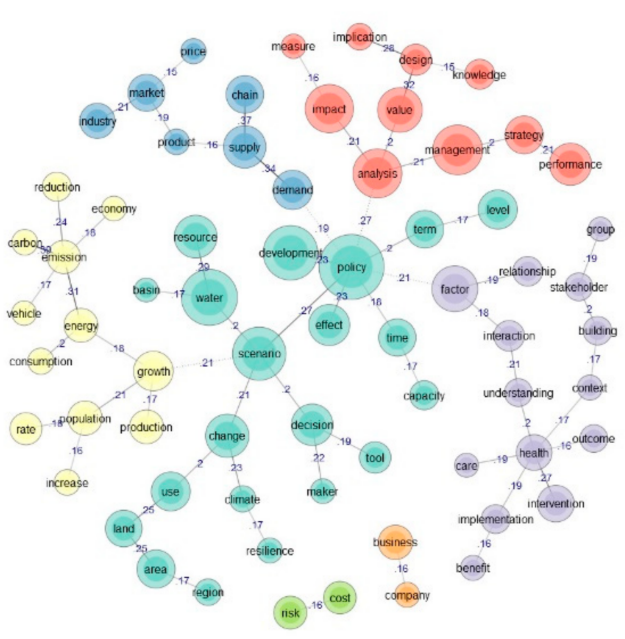

(a)

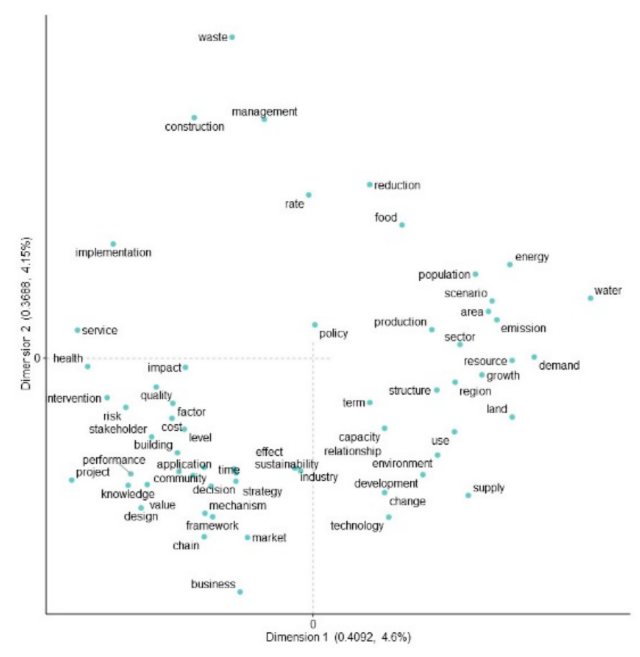

(b)

Figure 3. Examples of outcomes from the text-mining analyses: (a) co-occurrence network, terms frequency 50; edge distance Jaccard; (b) correspondence analysis of words, terms frequency 70, chi-square value top 60.

Table 3. Application domains.

\begin{tabular}{|c|c|c|}
\hline Group & Subgroup & Selected Topics \\
\hline Business & $\begin{array}{c}\text { Company level } \\
\text { Specific industrial segments }\end{array}$ & $\begin{array}{c}\text { Business performance } \\
\text { Project management } \\
\text { Market } \\
\text { Resource management } \\
\text { Supply chains } \\
\text { Material markets } \\
\text { Transport and traffic safety }\end{array}$ \\
\hline Environment & $\begin{array}{l}\text { Pollution } \\
\text { Agriculture }\end{array}$ & $\begin{array}{c}\text { Carbon production and emissions } \\
\text { Water } \\
\text { Sustainability } \\
\text { Agriculture general } \\
\text { Animals and fauna } \\
\text { Land use } \\
\text { Farming }\end{array}$ \\
\hline Health & & $\begin{array}{l}\text { Physical diseases } \\
\text { Health care and related areas }\end{array}$ \\
\hline Miscellaneous & & $\begin{array}{c}\text { R\&D and innovation } \\
\text { Social issues } \\
\text { Decision-making } \\
\text { Urban issues }\end{array}$ \\
\hline
\end{tabular}

The following sections present examples of topics that were analyzed by authors in selected studies. The most frequently analyzed issues are selected, and representative papers are mentioned. Specific values of any quantitative indicators, such as number of occurrences or ratios, were not used. Rather, rule of thumb was applied to obtain a reasonable structure and number of topics. Thus, the following paragraphs do not aim to enumerate the identified studies exhaustively. Only a digest enabling better insight into the SD environment is provided. 
Table 4. Study characteristics.

\begin{tabular}{|c|c|c|c|c|c|c|c|c|}
\hline Author & Date & Citation & Group & Subgroup & Selected Topics & Software & CLD & SFD \\
\hline Kim and Chung & 2016 & [4] & Business & Company level & Business performance & Vensim & Yes & Yes \\
\hline Cosenz and Noto & 2018 & [5] & Business & Company level & Business performance & Powersim & No & Yes \\
\hline Aparicio et al. & 2016 & [6] & Business & Company level & Business performance & Vensim, Stella & Yes & Yes \\
\hline Yun et al. & 2017 & [8] & Business & Company level & Business performance & Vensim & Yes & Yes \\
\hline Yan et al. & 2019 & [9] & Business & Company level & Business performance & Vensim & Yes & Yes \\
\hline Rocha et al. & 2019 & [10] & Business & Company level & Business performance & Vensim & Yes & No \\
\hline Anjomshoae et al. & 2017 & [11] & Business & Company level & Business performance & Unspecified & Yes & No \\
\hline Mhatre et al. & 2017 & [13] & Business & Company level & Project management & Vensim & No & Yes \\
\hline Wang et al. & 2017 & [14] & Business & Company level & Project management & Vensim & Yes & Yes \\
\hline van Oorschot et al. & 2018 & [15] & Business & Company level & Project management & Vensim & Yes & Yes \\
\hline Li et al. & 2018 & [16] & Business & Company level & Project management & Vensim & Yes & Yes \\
\hline Pargar et al. & 2019 & [17] & Business & Company level & Project management & Vensim & Yes & Yes \\
\hline Wang et al. & 2019 & [18] & Business & Company level & Project management & Vensim & No & Yes \\
\hline Abbaspour and Dabirian & 2019 & [19] & Business & Company level & Project management & Vensim & Yes & Yes \\
\hline Lee et al. & 2019 & [20] & Business & Company level & Project management & Unspecified & Yes & No \\
\hline Chung et al. & 2016 & [21] & Business & Company level & Resource management & Vensim & Yes & No \\
\hline Kunc and $\mathrm{O}^{\prime}$ Brien & 2017 & [23] & Business & Company level & Resource management & Vensim & No & Yes \\
\hline Alizadeh-Zoeram et al. & 2019 & [24] & Business & Company level & Resource management & Vensim & Yes & Yes \\
\hline Xing et al. & 2019 & [25] & Business & Company level & Resource management & Vensim & Yes & Yes \\
\hline Wang et al. & 2016 & [26] & Business & Company level & Resource management & Vensim & Yes & Yes \\
\hline Nair and Anbuudayasankar & 2016 & [27] & Business & Company level & Supply chain & Vensim & Yes & No \\
\hline Keilhacker and Minner & 2017 & [28] & Business & Company level & Supply chain & Unspecified & Yes & No \\
\hline Cagliano et al. & 2017 & [29] & Business & Company level & Supply chain & Vensim & Yes & Yes \\
\hline Zhang & 2016 & [30] & Business & Company level & Supply chain & Vensim & Yes & Yes \\
\hline Rawlins et al. & 2018 & [31] & Business & Company level & Supply chain & Vensim & Yes & No \\
\hline Choi & 2018 & [32] & Business & Company level & Supply chain & Vensim & Yes & Yes \\
\hline Armendáriz et al. & 2016 & [33] & Business & Company level & Supply chain & Vensim & Yes & No \\
\hline Chang and Lin & 2019 & [34] & Business & Company level & Supply chain & Unspecified & Yes & No \\
\hline Olafsdottir and Sverdrup & 2019 & [35] & Business & Company level & Supply chain & Unspecified & Yes & No \\
\hline Bahadir and Akdag & 2019 & [36] & Business & Company level & Supply chain & Vensim & Yes & Yes \\
\hline Jin & 2019 & [37] & Business & Company level & Supply chain & Unspecified & No & Yes \\
\hline Jeon and Yeo & 2017 & [38] & Business & Company level & Supply chain & Vensim & Yes & Yes \\
\hline
\end{tabular}


Table 4. Cont

\begin{tabular}{|c|c|c|c|c|c|c|c|c|}
\hline Author & Date & Citation & Group & Subgroup & Selected Topics & Software & CLD & SFD \\
\hline Tong et al. & 2019 & [39] & Business & Company level & Supply chain & Vensim & Yes & Yes \\
\hline Choi et al. & 2016 & [40] & Business & Specific industrial segments & Mineral markets & Powersim & Yes & Yes \\
\hline Sverdrup & 2016 & [41] & Business & Specific industrial segments & Mineral markets & Stella & Yes & Yes \\
\hline Wang et al. & 2018 & [43] & Business & Specific industrial segments & Mineral markets & Vensim & No & Yes \\
\hline Arango-Aramburo et al. & 2017 & [44] & Business & Specific industrial segments & Mineral markets & Vensim & Yes & No \\
\hline Liu et al. & 2019 & {$[45]$} & Business & Specific industrial segments & Mineral markets & Vensim & Yes & Yes \\
\hline Hazra et al. & 2019 & [46] & Business & Specific industrial segments & Mineral markets & Stella & No & Yes \\
\hline Zhang et al. & 2018 & [48] & Business & Company level & Market & Vensim & Yes & Yes \\
\hline Chung et al. & 2018 & [49] & Business & Company level & Market & Vensim & Yes & Yes \\
\hline Gonçalves & 2018 & [50] & Business & Company level & Market & Vensim & Yes & Yes \\
\hline Wang, Y. et al. & 2019 & [51] & Business & Company level & Market & Vensim & Yes & Yes \\
\hline Wang, J. et al. & 2016 & [52] & Business & Company level & Market & Vensim & Yes & Yes \\
\hline Yun et al. & 2019 & [53] & Business & Company level & Market & Vensim & Yes & Yes \\
\hline Pasaoglu et al. & 2016 & [54] & Business & Specific industrial segments & Transport and traffic safety & Unspecified & Yes & No \\
\hline Azmi and Tokai & 2017 & [55] & Business & Specific industrial segments & Transport and traffic safety & Vensim & No & Yes \\
\hline Wen and Bai & 2017 & [56] & Business & Specific industrial segments & Transport and traffic safety & Vensim & Yes & Yes \\
\hline Fontoura et al. & 2019 & [58] & Business & Specific industrial segments & Transport and traffic safety & Vensim & Yes & Yes \\
\hline Kim et al. & 2019 & [59] & Business & Specific industrial segments & Transport and traffic safety & Vensim & Yes & No \\
\hline Oliveira et al. & 2019 & [60] & Business & Specific industrial segments & Transport and traffic safety & Vensim & No & Yes \\
\hline Jeon et al. & 2016 & [61] & Business & Specific industrial segments & Transport and traffic safety & Vensim & Yes & Yes \\
\hline Estay-Ossandon and Mena-Nieto & 2018 & [62] & Environment & Pollution & Pollution & Vensim & No & Yes \\
\hline Gutberlet et al. & 2017 & [63] & Environment & Pollution & Pollution & Unspecified & Yes & No \\
\hline Phonphoton and Pharino & 2019 & [64] & Environment & Pollution & Pollution & Vensim & Yes & Yes \\
\hline Sukholthaman and Sharp & 2016 & [65] & Environment & Pollution & Pollution & Vensim & Yes & Yes \\
\hline Ardi and Leisten & 2016 & [66] & Environment & Pollution & Pollution & Unspecified & Yes & Yes \\
\hline Dasgupta et al. & 2017 & [67] & Environment & Pollution & Pollution & Stella & No & Yes \\
\hline Ghisolfi et al. & 2017 & [68] & Environment & Pollution & Pollution & Vensim & Yes & Yes \\
\hline Breach and Simonovic & 2018 & [69] & Environment & Pollution & Pollution & Vensim & Yes & Yes \\
\hline Nascimento et al. & 2018 & {$[70]$} & Environment & Pollution & Pollution & Vensim & Yes & Yes \\
\hline Prouty et al. & 2018 & [71] & Environment & Pollution & Pollution & Vensim & No & Yes \\
\hline Rinsatitnon et al. & 2018 & [72] & Environment & Pollution & Pollution & Stella & No & Yes \\
\hline Sea-lim et al. & 2018 & [73] & Environment & Pollution & Pollution & Stella & No & Yes \\
\hline
\end{tabular}


Table 4. Cont.

\begin{tabular}{|c|c|c|c|c|c|c|c|c|}
\hline Author & Date & Citation & Group & Subgroup & Selected Topics & Software & CLD & SFD \\
\hline Nedelciu et al. & 2019 & [74] & Environment & Pollution & Pollution & Unspecified & Yes & No \\
\hline Chinda et al. & 2018 & [75] & Environment & Pollution & Pollution & Stella & No & Yes \\
\hline Ding et al. & 2016 & [76] & Environment & Pollution & Pollution & Vensim & Yes & Yes \\
\hline Treadwell et al. & 2018 & [78] & Environment & Pollution & Pollution & Stella & No & Yes \\
\hline Xiao et al. & 2016 & [79] & Environment & Pollution & Emissions and pollution & Vensim & No & Yes \\
\hline Liu and Xiao & 2018 & [80] & Environment & Pollution & Emissions and pollution & Vensim & No & Yes \\
\hline Zhang et al. & 2018 & [81] & Environment & Pollution & Emissions and pollution & Unspecified & Yes & Yes \\
\hline Freeman et al. & 2016 & {$[83]$} & Environment & Pollution & Emissions and pollution & Vensim & Yes & No \\
\hline Scolozzi and Geneletti & 2017 & {$[84]$} & Environment & Pollution & Emissions and pollution & Vensim & Yes & No \\
\hline Navarro and Tapiador & 2019 & [85] & Environment & Pollution & Emissions and pollution & Vensim & No & Yes \\
\hline Zhao et al. & 2018 & [86] & Environment & Pollution & Emissions and pollution & Stella & No & Yes \\
\hline Liu et al. & 2017 & [87] & Environment & Pollution & Emissions and pollution & AnyLogic & No & Yes \\
\hline Scolozzi et al. & 2019 & [88] & Environment & Pollution & Emissions and pollution & Vensim & Yes & Yes \\
\hline Bixler et al. & 2019 & [89] & Environment & Pollution & Emissions and pollution & Vensim & No & Yes \\
\hline Chiu et al. & 2019 & [90] & Environment & Pollution & Emissions and pollution & Vensim & Yes & No \\
\hline Li, J.W. & 2019 & [91] & Environment & Pollution & Emissions and pollution & Vensim & No & Yes \\
\hline Matthew et al. & 2019 & [93] & Environment & Pollution & Emissions and pollution & Vensim & Yes & Yes \\
\hline Cordier et al. & 2019 & [94] & Environment & Pollution & Emissions and pollution & Powersim & No & Yes \\
\hline Dianati et al. & 2019 & [95] & Environment & Pollution & Emissions and pollution & Vensim & Yes & Yes \\
\hline Tseng et al. & 2019 & [96] & Environment & Pollution & Emissions and pollution & Stella & No & Yes \\
\hline da Silva et al. & 2019 & [97] & Environment & Pollution & Emissions and pollution & Vensim & Yes & No \\
\hline Ma et al. & 2018 & [98] & Environment & Pollution & Sustainability & Vensim & No & Yes \\
\hline Fouseki and Nicolau & 2018 & [99] & Environment & Pollution & Sustainability & Vensim & Yes & Yes \\
\hline Kotir et al. & 2016 & [100] & Environment & Pollution & Sustainability & Vensim, Stella & Yes & Yes \\
\hline Iandolo et al. & 2018 & [101] & Environment & Pollution & Sustainability & Vensim & Yes & Yes \\
\hline Liu et al. & 2019 & [102] & Environment & Pollution & Sustainability & Vensim & Yes & No \\
\hline Ulli-Beer et al. & 2017 & [103] & Environment & Pollution & Sustainability & Unspecified & No & Yes \\
\hline Wang et al. & 2016 & [104] & Environment & Pollution & Water & Vensim & No & Yes \\
\hline Baki et al. & 2018 & [105] & Environment & Pollution & Water & Vensim & Yes & Yes \\
\hline Qin et al. & 2018 & [106] & Environment & Pollution & Water & Vensim & Yes & Yes \\
\hline Garg et al. & 2019 & [107] & Environment & Pollution & Water & Vensim & Yes & Yes \\
\hline Hu et al. & 2018 & [108] & Environment & Pollution & Water & NetLogo & No & Yes \\
\hline
\end{tabular}


Table 4. Cont.

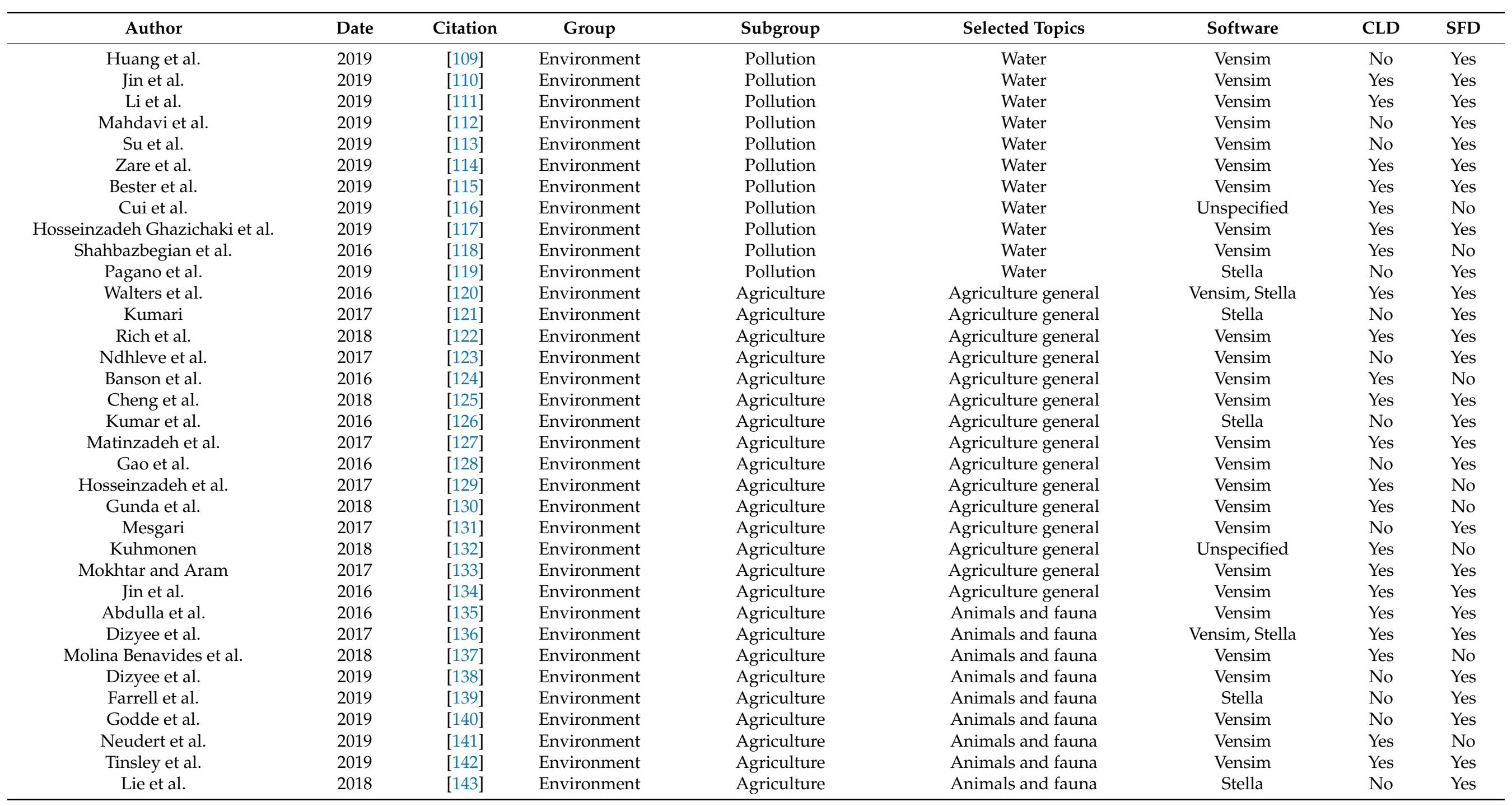


Table 4. Cont.

\begin{tabular}{|c|c|c|c|c|c|c|c|c|}
\hline Author & Date & Citation & Group & Subgroup & Selected Topics & Software & CLD & SFD \\
\hline Wallentin and Neuwirth & 2017 & [144] & Environment & Agriculture & Animals and fauna & NetLogo & No & Yes \\
\hline Crookes & 2017 & {$[145]$} & Environment & Agriculture & Animals and fauna & Vensim & No & Yes \\
\hline Pérez et al. & 2016 & [146] & Environment & Agriculture & Animals and fauna & Vensim & No & Yes \\
\hline Herrera & 2017 & [148] & Environment & Agriculture & Animals and fauna & Vensim & Yes & Yes \\
\hline Rodríguez-Izquierdo et al. & 2019 & [149] & Environment & Agriculture & Animals and fauna & Vensim & Yes & Yes \\
\hline Liu et al. & 2017 & [150] & Environment & Agriculture & Land use & NetLogo & Yes & No \\
\hline Dang et al. & 2017 & [151] & Environment & Agriculture & Land use & Unspecified & Yes & No \\
\hline de Freitas et al. & 2018 & [153] & Environment & Agriculture & Land use & NetLogo & No & Yes \\
\hline Park and Park & 2018 & [154] & Environment & Agriculture & Land use & Stella & Yes & Yes \\
\hline Sanga and Mungatana & 2016 & [155] & Environment & Agriculture & Land use & Stella & No & Yes \\
\hline Lim et al. & 2017 & [156] & Environment & Agriculture & Land use & Vensim & Yes & No \\
\hline Yurike et al. & 2018 & [157] & Environment & Agriculture & Land use & Unspecified & Yes & No \\
\hline Nazir and Ahmad & 2018 & [158] & Environment & Agriculture & Land use & Stella & Yes & Yes \\
\hline Forero Montaña et al. & 2019 & [159] & Environment & Agriculture & Land use & Stella & No & Yes \\
\hline Fuglestad and Palmer & 2019 & [160] & Environment & Agriculture & Land use & Stella & Yes & Yes \\
\hline Tan et al. & 2019 & [161] & Environment & Agriculture & Land use & Vensim & No & Yes \\
\hline Von Loeper et al. & 2016 & [163] & Environment & Agriculture & Farming & Vensim & Yes & Yes \\
\hline Lie and Rich & 2016 & [164] & Environment & Agriculture & Farming & Vensim & Yes & Yes \\
\hline Koláčková et al. & 2017 & [165] & Environment & Agriculture & Farming & Vensim & Yes & Yes \\
\hline Ha et al. & 2017 & [166] & Environment & Agriculture & Farming & Vensim & Yes & No \\
\hline Kopainsky et al. & 2017 & [167] & Environment & Agriculture & Farming & Vensim & Yes & No \\
\hline Kopainsky et al. & 2019 & [168] & Environment & Agriculture & Farming & Vensim & Yes & No \\
\hline Sjaifuddin et al. & 2019 & [169] & Environment & Agriculture & Farming & Powersim & Yes & Yes \\
\hline Sugiyama et al. & 2017 & [170] & Health & & Physical diseases & Vensim & No & Yes \\
\hline Rogers et al. & 2018 & [171] & Health & & Physical diseases & Stella & Yes & Yes \\
\hline Chen et al. & 2018 & {$[172]$} & Health & & Physical diseases & Unspecified & Yes & No \\
\hline Carrete et al. & 2017 & [173] & Health & & Physical diseases & Stella & No & Yes \\
\hline Liu et al. & 2016 & [174] & Health & & Physical diseases & Vensim & No & Yes \\
\hline Jalali et al. & 2019 & [175] & Health & & Physical diseases & Vensim & Yes & Yes \\
\hline Safarishahrbijari et al. & 2017 & [176] & Health & & Physical diseases & Unspecified & No & Yes \\
\hline Powell et al. & 2018 & [177] & Health & & Physical diseases & Vensim & Yes & No \\
\hline Kianmehr et al. & 2019 & [178] & Health & & Physical diseases & Vensim & No & Yes \\
\hline van Ackere and Schulz & 2019 & [179] & Health & & Physical diseases & Vensim & No & Yes \\
\hline
\end{tabular}


Table 4. Cont.

\begin{tabular}{|c|c|c|c|c|c|c|c|c|}
\hline Author & Date & Citation & Group & Subgroup & Selected Topics & Software & CLD & SFD \\
\hline Cruz et al. & 2019 & [180] & Health & & Physical diseases & Vensim, Stella & Yes & Yes \\
\hline Renmans et al. & 2017 & [181] & Health & & Health care and related areas & Vensim & Yes & No \\
\hline Hilmola and Henttu & 2016 & [182] & Health & & Health care and related areas & Vensim & Yes & No \\
\hline Ishikawa et al. & 2017 & [184] & Health & & Health care and related areas & Stella & Yes & Yes \\
\hline Jetha et al. & 2016 & [185] & Health & & Health care and related areas & Vensim & No & Yes \\
\hline Farid et al. & 2019 & [186] & Health & & Health care and related areas & Vensim & Yes & Yes \\
\hline McAvoy et al. & 2019 & [187] & Health & & Health care and related areas & Vensim & Yes & No \\
\hline Zhang et al. & 2019 & [189] & Health & & Health care and related areas & Vensim & No & Yes \\
\hline Luna-Reyes et al. & 2018 & [190] & Health & & R\&D and innovation & Vensim & No & Yes \\
\hline Wang & 2019 & [191] & Miscellaneous & & $\mathrm{R} \& \mathrm{D}$ and innovation & Vensim & Yes & Yes \\
\hline Lansu et al. & 2019 & [192] & Miscellaneous & & R\&D and innovation & Vensim & Yes & No \\
\hline Lee & 2019 & [193] & Miscellaneous & & R\&D and innovation & Unspecified & Yes & No \\
\hline Mendes and Aleluia & 2019 & [194] & Miscellaneous & & R\&D and innovation & Vensim & No & Yes \\
\hline Mobus & 2018 & [195] & Miscellaneous & & R\&D and innovation & Unspecified & No & Yes \\
\hline Howard and Thompson & 2016 & [196] & Miscellaneous & & R\&D and innovation & Unspecified & Yes & No \\
\hline Davies et al. & 2016 & [197] & Miscellaneous & & Social issue & Vensim & Yes & No \\
\hline Stringfellow & 2017 & [199] & Miscellaneous & & Social issue & Vensim & Yes & Yes \\
\hline Hossain et al. & 2017 & [200] & Miscellaneous & & Social issue & Stella & Yes & No \\
\hline Givens et al. & 2018 & {$[201]$} & Miscellaneous & & Social issue & Vensim & Yes & No \\
\hline Ford and White & 2019 & [202] & Miscellaneous & & Social issue & Vensim & Yes & Yes \\
\hline Zhu and Liu & 2017 & [203] & Miscellaneous & & Social issue & Vensim & Yes & Yes \\
\hline Ibáñez and Martínez-Valderrama & 2018 & [204] & Miscellaneous & & Decision-making & Vensim & Yes & No \\
\hline Zabid and Abidin & 2017 & [205] & Miscellaneous & & Decision-making & Vensim & Yes & Yes \\
\hline Macmillan et al. & 2016 & [206] & Miscellaneous & & Decision-making & Vensim & Yes & No \\
\hline Yan & 2018 & [207] & Miscellaneous & & Decision-making & Vensim & No & Yes \\
\hline $\mathrm{Bao}$ and $\mathrm{He}$ & 2019 & [208] & Miscellaneous & & Urban issues & Vensim & Yes & Yes \\
\hline Fang et al. & 2019 & [209] & Miscellaneous & & Urban issues & Vensim & No & Yes \\
\hline Li, G. et al. & 2019 & [210] & Miscellaneous & & Urban issues & Vensim & Yes & Yes \\
\hline Li, Y. et al. & 2019 & [211] & Miscellaneous & & Urban issues & Vensim & Yes & No \\
\hline Liu et al. & 2019 & [212] & Miscellaneous & & Urban issues & Stella & No & Yes \\
\hline Shrubsole et al. & 2019 & [213] & Miscellaneous & & Urban issues & Vensim & Yes & No \\
\hline Sing et al. & 2019 & [214] & Miscellaneous & & Urban issues & Vensim & Yes & Yes \\
\hline Moradi et al. & 2019 & [215] & Miscellaneous & & Urban issues & Vensim & Yes & Yes \\
\hline
\end{tabular}




\subsection{Business}

\subsubsection{Business Performance}

The dynamics of social capital and business performance were described in [4]; in this schema, the discovery of the simulation included the prediction of organizational capacity, market competitiveness, innovation capacity, cost, competitiveness, operational performance, financial performance, relationship commitment, and trust. SD was used for experimenting with new business venture strategies, and the results of the simulation were the prediction of the cost of customer acquisition and customer lifetime value [5]. SD was used for the Colombian business cycle, and the outcomes of the simulation were represented by five predictions of GDP of Colombia [6]. The coexistence of airlines and airports was described in [7], and the results of the simulation were the prediction of airline and airport financial stocks. SD was used for the growth of a platform business; the findings of the simulation were the prediction of revenue for Apple and Android, as well as hotel and bookings revenue [8]. To enhance decision-making processes during e-business innovations, SD models were used to analyze performance and the impacts of decisions [9]. A combination of knowledge-based system for decision support, management flight simulations, and SD models allowed better resource allocation and improved managerial decision-making rationale during e-business innovation projects. Results can be applied to agile IT project management as well. Rocha et al. [10] focused their research on economic performance using cluster policies. A theoretical model based on SD principles was developed. The results showed that even clusters that have positive economic performance can be mitigated by negative social feedback. The results have the potential to influence policy making in a positive way, to improve the cohesion relationship between economic and social performance factors. Performance management was discussed in [11], where causal loop diagrams (CLDs) were used to capture critical variables of beneficiaries and the perspectives of donors, internal processes, earning and innovation, and finance. $\mathrm{Yu}$ et al. [12] presented an SD model named the industry-effect policy to analyze environmental and economic effects of eco-industry. The stock-and-flow diagram (SFD) captures blast furnace gas, calcium carbide furnace gas, submerged arc furnace gas, coke furnace gas, and policy-preferential industrial sectors. Outputs of the simulation were the prediction of the impact of presented policies, and the demand for selected gas up to the year 2030. The model also allowed an analysis of the regulation options for industrial sectors seeking transformation toward eco-industry.

\subsubsection{Project Management}

Several papers have been written with a focus on projects. In relation to an Indian construction project, Mhatre et al. [13] were able to predict risk factors for 12 months by instantaneous risk variables. Project implementation under uncertainty with a focus on usage and simulation of available data can be used for the prediction of expected and realized value [14]. The authors also focused on new product development projects that exhibited the possibility of predicting the new product's profitability [15]. The impact of labor controls on large complex projects was presented in [16]. Results of the simulation were the prediction of project progress. CLDs were used in the domain of project management. Pargar et al. [17] showed an application of CLD when managing a project alliance. All participating parties are required to share risks, make unanimous decisions, and work efficiently together. Research was focused on four value creation processes: work progression, rework, redesign and innovation, and rescheduling. CLD proved to be an efficient tool in discovering the interrelationships among these core processes, allowing the development of the stock and flow model of the SD. Another study [18] that was similarly focused on project portfolio management showed the use of SD models with emphasis on dealing with uncertainty and interdependencies. Handling a project portfolio is naturally a more challenging task than managing individual projects, but SD tools have been proven to be efficient support tools in visualizing portfolio structure and behaviors under various conditions. A study by Abbaspour and Dabirian [19] used SD models for assessment 
of different labor hiring policies for construction projects. The resulting models can be used for managerial decision support and to help identify efficient allocation of human resources. For construction projects, human resource management is crucial because it is closely related to the relative costs of implementing construction projects. Especially important in this context is estimation and supply of the project labor required. Policies were divided into two categories: those based on time (hiring intervals) and those based on labor (work crew) composition. A paper of Lee et al. [20] focused on the economic feasibility of apartment development projects. System dynamics was used in the model using a case study with a 1794-unit development project. The model was able to forecast, control, and manage various risk factors and simulate their impact, even if they dynamically change during the development project.

\subsubsection{Resource Management}

In this realm we identified papers focused on resource mapping used for capturing critical-variable human resource development [21], human resource planning for capturing critical variables of organizational human resources [22], or resource mapping, which provided predictions for IN-store café shops and revenues of i-store café shops [23]. Human resource dynamics is also important in medical services, where the phenomenon of a socalled "death spiral of quality" sometimes occurs. As stated by Alizadeh-Zoeram et al. [24], it is mostly a lack of systemic thought that considers the feedback relationships between numerous effective variables in the system performance. SFD and CLD were used to model human resources service capacity in a hospital clinic environment as a case study. The relationships among the economy, resources, and the environment were studied with SD models by Xing et al. [25]. Outputs of the simulation were the prediction of GDP, energy consumption, chemical oxygen demand, sulfur dioxide accumulation, solid waste, and population up to the year 2028 under seven different scenarios. Project managers' encounter was explored in [26], who presented results of the simulation use for the prediction of an adaption rate. There were also other topics in this group dealing with the performance management approach, apartment brand management, and risk management.

\subsubsection{Supply Chain}

The benefits of information and communication technologies (ICT) in supply chain management were researched in [27], where CLD was used to capture the critical variable of inventory control. SD was used for supply chain risk management of rare earth elements [28], e-grocery [29], closed-loop supply chain finance risk [30], service value chain [31], and mobile value chain [32]. The study of Armendáriz et al. [33] used SD for analysis of food supply chains, in order to achieve a sustainable agricultural system. In the study, the authors identified a set of critical factors having significant impact on sustainability and resilience of the agricultural production and distribution systems. Another research study with a similar aim was presented by Chang and Lin [34]. The attention was focused more on logistics aspects of the supply chain, such as a supplier's replenishment lead time or the impact of various disruptive events. The functioning of food supply chains from a market mechanics perspective was studied by Olafsdottir and Sverdrup [35]. Models used causal links, and dynamic feedback was used to parametrize price functions on selected food markets. Results allowed the optimization of supply chain models parameters. The system dynamics model of Bahadir and Akdag [36] was used for optimizing transportation planning. The model works with container capacity, shipping and planning processes, warehouse capacity for expansion, and container lifetime. The simulation model improved the prediction of container fleet size and resource use rate, with a focus on the tactical level of container transportation. An aspect of sharing information among partners within the supply chain was studied in [37]. CLD compared cases of supply chains with and without information sharing. Four different scenarios were considered, and results of the simulation showed that sharing customer demand information is generally better than sharing retailer sales, and information sharing improves supply chain flexibility and allows optimization 
of inventory levels. The timing of ship orders was discussed in [38]. CLD captured the supply and demand of ship transportation in China. Results of SFD simulation were the optimal prediction timing for a ship order placement, price of new container ships, and price of second-hand container ships. Based on outputs from the simulation, three optimal timing scenarios were developed for ship order placement. The paper of Tong et al. [39] is focused on the research of consumers' environmental preferences. Retailer-led supply was used in an evolutionary game used to examine the behavior of consumers and retailers. The simulation results showed that there is a preference for low-carbon products. The study suggests that retailers' and manufacturers' strategy should be adjusted accordingly to adapt to consumers' environmental preferences and maintain sustainable production in the long-term perspective.

\subsubsection{Mineral Markets}

Several papers related to the markets with minerals have been published focusing on indium [40], lithium [41], platinum group metal [42], coal [43], gold, and limestone [44]. The paper [45] is focused on supply and demand dynamics of trading with lithium. The study focused on factors influencing trends in market prices, namely the emergence of renewable energy technologies such as electric energy storage and new energy vehicles. Results indicated a significant future role for electric energy storage and suggested measures to handle supply shortages and import risks. Another practical application of a SD model in the mining industry was presented by Hazra et al. [46]. The paper focused on Indian iron ore mining, more specifically real option valuation of the ore deposits. The planning processes require estimation of many parameters, as it is difficult to obtain or predict exact values during the preparation phase for the long-term mine plan. An SD model works with various stochastic parameters and has been proven to be a viable and more efficient alternative to more traditional methods. Outputs of the simulation were the prediction of iron ore price, extraction rate, and the production of iron ore for 15 years. Another application of SD models in the mining industry is focused on sustainable production of copper, zinc, and lead [47]. The model was used for the estimation of market price movements rather than production itself. The model showed that market prices are expected to rise in the following decades (approximately up to the end of the 22nd century) and become more volatile. The study showed the importance of policy changes regarding resource efficiency and resource conservation, and advocated for strong policies to promote the recycling of metals.

\subsubsection{Market}

Chinese urban housing markets were analyzed though SD. In [48], the authors developed a simulation model that enables the prediction of housing prices. The impact of deregulation on the price of rice in Malaysia was simulated in [49], which enables prediction of the wholesale price, paddy rice price, paddy production, rice production, and rice demand. Demand bubbles were researched in [50]; the main outcomes of simulations included the prediction of backlog, shipments, and capacity, delivery delay, and cancelations. Y. Wang et al. [51] analyzed power-grid financial capacity in China. SFD captured electricity sales, transmission and distribution costs, and revenue, profit, financing, and depreciation. Outputs of the simulation were the prediction of electricity sales, electricity purchase, and transmission capacity up to the year 2025. Juite Wang et al. [52] analyzed Taiwan's mobile application market. Based on the analysis, the authors created CLD focused on developers and customers. The authors then constructed SFD and one base scenario, and two specific scenarios for simulations; the simulation's main findings were the prediction of download share and app share. Yun's paper [53] focused on market growth, investigating the difference between already established and newly appearing market-based emerging industry. The simulation results were the prediction of the technological market under several different scenarios for 10 years. The paper shows that advanced business models 
are highly important for a converted industry, especially for fast and substantial growth of the initial market.

\subsubsection{Transport and Traffic Safety}

There are various studies focusing on transport-related topics. Scenarios of the lightduty vehicle road transport sector were presented in [54]. Acquired simulation outcomes were used for prediction of new sales market share, the evolution of average real-world $\mathrm{WtW} \mathrm{CO} 2$ emissions, and EU energy consumption. The future of electric vehicles in Malaysia was presented in [55], which enables prediction of new vehicle registration. The case study of traffic policy for Beijing was described in [56]. The presented results of the simulation helped with the prediction of carbon emissions created by vehicles, vehicles energy consumption and variation of the type of vehicles. Another Beijing-based study investigated taxi management in this city. Results were useful for the prediction of attraction coefficient, service level, empty-loaded rate, daily carrying frequency per taxi, total demand for 120 h, empty, loaded rate, and total demand [57]. Fontoura et al. [58] focused on Brazilian urban mobility policy, with a case of São Paulo. SFD and CLD captured the Brazilian urban transport system. Outputs of the simulation were the prediction of usage of public transport, level of policy implementation, and the amount of $\mathrm{CO}_{2}$ under three different scenarios for 30 years. Kim, Lee, and Ahn [59] dealt with the transition to aviation biofuel in the socio-technical perspective. CLD captured the interaction between the aviation regime and the biofuel niche. Oliveira et al. [60] focused on the diffusion of alternative fuel vehicles. SFD captured the process of choosing new vehicles. Outputs of the simulation were the prediction of the market of alternative fuel vehicles up to the year 2053. Safety ship policy recommendations were made for Korea. The simulation model was used for the prediction of ship accidents, ship safety, and marine safety [61].

\subsection{Environment}

\subsubsection{Pollution}

The sample of research papers contains various papers focused on environmental pollution. Although not presented here as one specific domain, waste-related papers can be found with a focus on several types of waste such as solid waste [62-65], e-waste [66-68], liquid waste [69-71], paper recycling [72], steel [73] or phosphorus in urban wastewater [74], construction waste $[75,76]$, and food waste $[77,78]$.

\subsubsection{Emissions and Pollution}

Several articles about the carbon emission target in China have been published. The first paper targeted the year 2020, and the results of the scenarios were the predictions of the consumption of mineral resources, electrical energy generation, and carbon emission [79]. The second paper had a target of 2025. The outcomes of the simulation were the prediction of coal, oil, natural gas, hydropower, nuclear power, wind power, GDP, population, and the production of carbon emissions [80]. The third paper had a target of 2030, and the results of the simulations were the prediction of carbon emissions and carbon emissions intensity [81]. The target of greenhouse gas until 2030 in China was described in [82]; the results of the simulation were the prediction of exports, carbon emission intensity, energy intensity, and household welfare. SD has been used to revisit Jevons' paradox; the outputs of the simulation were the prediction of carbon emissions per person, non-freight travel, fleet efficiency, and cost of the road [83].

Emissions in the anthroposphere were described in [84], where CLD was used to capture a critical-variable climate change paradigm. Navarro and Tapiador [85] focused on rural socioeconomic issues and reasons for rural migration. SFD and CLD were made from modules: economic, social, demographic, and attractiveness. The authors created 36 scenarios. The main findings were these: small villages may be incapable of producing economic development; and education, health, and public infrastructure are the most relevant services that help to retain the population. Carbon-labeled products were discussed 
in [86]; the results of the simulation were the prediction of the probability of customers buying a product, and the probability of enterprise labeling. Low-carbon products were discussed in [87], where SFD was used as part of the hybrid model related to consumer and low-carbon products. Scolozzi, Schirpke, and Geneletti [88] focused on ecosystem services management. SFD and CLD captured regeneration and extraction of resources, and environmental quality. Outputs of the simulation were the prediction of environmental quality and the number of visitors under three different scenarios for 20 years. Bixler et al. [89] focused on life cycle assessment of green infrastructures. SFD captured catchment area and green infrastructure. Chiu et al. [90] focused on the impact of the change of coastal land use in the Chiku coastal zone in Taiwan on regional carbon balance. The authors created CLD to capture the main feedback loops of land-use change. Outputs of the simulation were the prediction of the creation and absorption of carbon dioxide up to the year 2070. Li [91] focused on the greenhouse effect. SFD and CLD captured the $\mathrm{CO}_{2}$ cycle. Outputs of the simulation were the prediction of the total amount of $\mathrm{CO}_{2}$ for 50 years under several different scenarios. Li, Liu, and Zhang [92] focused on economic transformation and environmentally coordinated development. SFD and CLD captured the economy, energy consumption, carbon emissions, and social development. Outputs of the simulation were the prediction of asset investment, GDP, energy consumption, and $\mathrm{CO}_{2}$ emissions under three different scenarios up to 2029. Matthew et al. [93] focused on low carbon usage on island systems. SFD and CLD captured electricity systems on an isolated island. Outputs of the simulation were the prediction of renewables' aggregated capacity, fossil generation capacity, and energy storage capacity up to 2050. Cordier and Uehara [94] dealt with the impact of innovation and policies on the amount of plastic in oceans. Outputs of the scenarios were the prediction of the amount of plastic in oceans up to 2030 under several different scenarios. Dianati et al. [95] investigated air pollution created in Nairobi's slums. The authors used CLD to capture the main driving forces of household air pollution. Outputs of the simulation were the prediction of household air pollution and coverage of clean appliances up to 2039 under several different scenarios. Tseng, Lee, and Chen [96] explored hexavalent chromium concentration in water. SFD captured the relationships among river water, sediment, and soil. Outputs of the simulation were the prediction of the amount of hexavalent chromium in river water, sediment, and soil for 15 years. Da Silva et al. [97] applied SD as one step in the prevention of natural disasters. The authors used CLD to capture the dynamics of the main driving factors in disasters (e.g., risk analysis, and losses and damages).

\subsubsection{Sustainability}

SD was used for technology related to sustainable development; the findings of the simulation were the prediction of the value of soil testing and a comparison of the production of new phosphate fertilizer and traditional phosphate fertilizer [98]. SD was used for sustainable lifestyles, where CLD and SFD were used to capture key variables of sustainable heritage-led regeneration [99]. SD was used for sustainable water resources, and the outputs of the simulation were the prediction of crop yield, agricultural water demand, net-farm income, domestic water demand, total population, and industrial water demand [100]. SD was also used to define sustainable value; CLD and SFD were used to capture key variables of sustainable value [101]. P. Liu et al. [102] analyzed narrow energy performance gaps. CLD captured energy consumption gaps in general. SFD was applied to a specific case in China. The main conclusions were these: (1) facility managers should pay less attention to austerity occupants; and (2) facility managers should pay more attention to standard occupants to enhance their energy-saving awareness. In [103], socio-technical transitions were presented in the case of specific energy transition, where CLD was used to capture key variables related to self-consumption communities. 


\subsubsection{Water}

SD has seen use for models of drinkable water. Articles have mainly been focused on distribution, demand, and usage of water. For instance, SD was used to capture irrigation water demand in Baojixia, China [104], water demand in urban areas [105], and water demand for megacities [106].

Garg and Azad [107] focused on Cauvery water-sharing awards. SFD and CLD captured allocations of the Analytical Framework Model. Outputs of the simulation were the prediction of the allocation of water and water availability. Hu et al. [108] focused on food, water, and energy systems in sustainable resources management. SFD captured the usage of water. Outputs of the simulation were used for the prediction of reservoir water storage under several different scenarios for 12 months. Huang et al. [109] focused on the impact of water regulations on environmental water stress. SFD captured resources dependent on water (e.g., rice, wheat, cotton). Outputs of the simulation were represented by the prediction of the water stress index. Jin et al. [110] focused on sustainable development of water, energy, and food in China. SFD and CLD captured water, energy, and the food system. The prediction of the consumption of water, energy, and food under several different scenarios up to the year 2026 were the main simulation outputs. $\mathrm{Li}$ et al. [111] investigated change in the drought-limited water level of a reservoir. SFD and CLD captured the usage and accessibility of water. Outputs of the simulation were used for the prediction of the amount of water demand, desalinated seawater, shallow groundwater, and deep groundwater up to 2020. Mahdavi, Bagheri, and Hosseini [112] focused on water for an integrated assessment. SFD captured the main variables related to saltwater and inland water resources and their usage. Outputs of the simulation were the prediction of agriculture crop area, agricultural employment, agricultural consumption, and the level of groundwater. Su, Gao, and Guan [113] focused on water security systems in Japan. SFD captured the economy, population, water resources, the water environment, and water disasters. Zare et al. [114] explored an integrated water resource. SFD and CLD captured population, land use, and water resources. Outputs of the simulation were the prediction of the consumption of water by urban, agriculture, and vegetation area, and agricultural GDP under different scenarios for 35 years. Bester, Blignaut, and Crookes [115] focused on the economic lifespan of the proposed Ntabelanga and Laleni dams in South Africa. SFD and CLD captured the main variables related to dams. Simulation outputs were used for the prediction of environmental degradation. Cui et al. [116] focused on social economy and the water environment in a case study of Kunming. CLD captured socioeconomic issues and the water environmental system. Outputs of the simulation were the prediction of population, water consumption, and GDP up to 2024. Hosseinzadeh Ghazihaki and Monem [117] focused on irrigation networks. SFD captured the control systems of irrigation. SD was used to analyze the hydro politics of the Helmand transboundary river. CLD was used to capture critical variables related to the hydro environment [118]. Pagano et al. [119] explored risk reduction. SFD captured the main variables related to the flood. Outputs of the simulation were the prediction of primary impacts, socio-institutional dynamics, and land use under several scenarios for 50 years.

\subsubsection{Agriculture}

As the quantitative analysis suggests, agriculture-related studies have used SD as a modeling approach quite often. Various topics such as agricultural production systems have been explored with the help of both types of diagrams associated with SD.

In [120], both CLDs and stock-and-flow diagrams were used to capture critical variables of economics, crop production, environmental quality, livestock production, and social quality. A case study of economic development driven by agricultural growth in the Patna Region of India was presented in [121]. The results of the simulation were a prediction of population, population density, income per capita, agricultural outputs, and GDP. SD was used for urban and peri-urban agriculture planning; CLD and SFD were used to capture critical-variable organic urban farming in Christchurch [122]. A case study from 
Cape Province in South Africa was focused on public spending on agriculture and poverty, with findings of the simulation being the prediction of poverty [123]. A case study from Ghana presented drivers and barriers for sustainable agriculture; CLD and SFD were used to capture critical-variable livestock systems, fishery systems, horticultural systems, and agricultural systems of Africa [124]. Another case study focusing on sustainable agriculture was from the Three Gorges Reservoir region of China, where outputs of the simulation were the prediction of the poverty level, sewage discharge, human disease, forest area, earthquake frequency, crop yield, use of fertilizers, use of pesticides, crop disease, and cultivated land [125]. Three papers were devoted to nitrogen dynamics in soil [126]: findings of the simulation of the first paper were the prediction of Detritus- $\mathrm{N}$ concentration data; in the second paper a prediction of the drainage rate, NO3 drainage water, and NH4 drainage water [127]; and the third paper featured the prediction of oxidized $\mathrm{N}$ deposition, fertilizer $\mathrm{N}$ application, net food and feed $\mathrm{N}$ imports, and agricultural $\mathrm{N}$ fixation [128]. Two papers were focused on irrigation. The first one was in the view of hydromechanical gates, where CLD was used to capture the critical variable of control systems in irrigation networks [129]. The second paper was focused on sociocultural feedbacks for the irrigation system; CLD was used to capture the critical variable of acequia mutualism [130]. Policy recommendations for the agricultural system in Iran were presented in [131]; the discovery of the model can be summarized as the economical and agricultural indicators. The future of wicked problems was addressed by the common agricultural policy; CLD was used to capture critical variables related to common agricultural policy [132]. A case study of agricultural groundwater management on the Firuzabad Plain in Iran was presented in [133], where results of the simulation were the prediction of groundwater level and benefit to farmers. The impact of land consolidation in China was analyzed in [134]; here, the discoveries of the simulation were the prediction of agriculture labor transfer, the secondary and tertiary industry labor, regional GDP, and social conflict.

\subsubsection{Animals and Fauna}

SD has been used for analysis of the beef sector. Beef cattle production in Malaysia was investigated in [135]. The potential of policies focused on the beef sector in Botswana was explored by [136]. Findings of the simulation were represented by the prediction of total cattle population, adult cattle price, weaner price, producers' profit, Botswana meat commission gross profit, feedlots profit, traditional butchers' profit, and modern butchers and retailers. Description of heat stress in dairy cows was done in [137], where CLD was used to capture critical variables of cow dynamics in heat conditions. The SFD was used to study the impact of policy interventions in the smallholder dairy value chain in Tanzania [138]. Results indicated a negative impact of both short-term (1 year) and medium-term ( 5 year) policies on income due to the higher cost of artificial insemination of local-breed cows. The simulation model captured milk production, profit, and consumption rates of milk up to the year 2034. Another study on flock productivity focused on the development of sheep and beef farms in New Zealand [139]. Changes in the value of meat and wool caused a shift of production focus from wool production to sales of animals for slaughter. A SD model was constructed to estimate the quality of sheep and beef farm production, income from sheep sales, and the wastage rate of stock in the timeframe of 30 years. Godde et al. [140] focused on the impact of climate change on grazing herds, with a case study from Australian rangelands. SFD captured forages biomass and cattle population. Outputs of the simulation were the prediction of standing dry matter, animal stocking rates, and precipitation under several different scenarios for 30 years. Neudert and Salzer [141] applied system archetypes on common village pasture problems in the South Caucasus. The tragedy of the commons, the shifting of the burden, and the success of successful archetypes were used. Tinsley et al. [142] focused on cow herd dynamics. SFD captured the life cycle of cattle. Outputs of the simulation were the prediction of several mature cows, forage consumption, the cost of a cow, and net income for 121 months. An empirical evaluation of policy options for development in Nicaragua was done by SDA; 
findings of the simulation were the prediction of milk production, farmer profit, total cattle population, and land use [143].

The original Lotka-Volterra predator-prey model was redesigned and introduced in [144]; the results of the simulation were the prediction of the fish population and plankton biomass. SD was used for solving the question of the price of rhino horn and the prevention of poaching; SFD was used to capture critical variables related to poaching [145]. SDM was used to capture the dynamics of the Oestrus population; outcomes of the simulation were the prediction of the stage of larvae of Oestrus [146]. Viability of the critically endangered Cat Ba langur was researched in [147], CLD was used to capture key variables related to the Cat Ba langur. Analysis of resilience was done by SDM; CLD and SFD were used to capture critical variables of the Kaibab deer population [148]. Rodríguez-Izquierdo et al. [149] focused on crafting environmental regulations. SFD and CLD captured the environment and socio-economy. Outputs of the simulation were the prediction of whale abundance.

\subsubsection{Land Use}

SD has been used for land use description and analysis in several cases. A new method for simulation of land-use changes was presented in [150], where CLD was used to capture key variables related to land use in Beijing. Biophysical and socioeconomic factors for land use in agricultural economic regions were presented in [151]. Outputs of the simulation were the prediction of land use in these areas. Scenarios for land use in the Chaobai River region of Jing-Jin-Ji in China were shown in [152]. Findings of the simulation were the prediction of cultivated land, woodland, grassland, water area, construction land, and unused land. The change of land use in the Upper Uruguay Basin (Brazil) was presented in [153], where data of the simulation were used for the prediction of forest grass, silviculture, mixed semi-subsistence agriculture, large-scale agriculture, urban uses, and water. The influence of population growth on land use was analyzed in [154]. The main results of the simulation were represented by the prediction of an increase in the rate of urban flood risk. Land use externality was discussed in [155]; results of the simulation were the predicted area of natural vegetation, net revenue from paddy production, net revenue from banana production, net revenue from orange production, net revenue from mango production, sediment load in water flowing downstream, and the social well-being of the community.

SD has been used to analyze deforestation in Myanmar, where CLD was used to capture key variables of the deforestation process [156]. Another paper related to deforestation focused on Dharmasraya District in West Sumatra, Indonesia; in that study, CLD was used to capture key variables of the deforestation process [157]. Another paper was focused on deforestation in Pakistan, where outcomes of the simulation were the prediction of forest area, usage of land including built-up area expansion, total built-up area, cultivated area expansion, total cultivated area, rangeland expansion, total rangeland area, and net change to inland areas [158]. Another study focused on forest management planning [159]. The proposed model served as a growth simulator that allows forecasting of growth, yield, replanting, and other aspects important for managerial decisions. The study of Fuglestad and Palmer [160] focused on land ownership, property laws, and land distribution in Norway. The study combined historical data with a SD model, which combined a coverage period between 1814 and 2014. SFD captured the dynamics of landowners, huntsmen, and tenant farmers. The SFD has also been used to study landscape dynamics of the natural ecosystem [161]. The model took under consideration possible socioeconomic and natural impacts of ecosystem management. Over the period from 2000 to 2010, the model captured the dynamics of landscape degradation as the result of the expansion of farmland, tea gardens, and rubber plantations. The simulation combined SD, MaxEnt, and cellular automata models. Results demonstrated the effective simulation of the natural ecosystem and prediction of its development under varying conditions. 


\subsubsection{Farming}

A case study for smallholder farmers in Maharashtra in India was introduced in [162]. CLD was used to capture the critical variable of smallholder farmers. SD was used for the analysis of smallholder farmers' challenges in South Africa; findings of the simulation were the prediction of smallholder productivity [163]. A case study of smallholder dairy value chains in Nicaragua was presented in [164]. SFD and CLD were used to capture critical variables of smallholder dairy value chains. The dynamic of small farmers' behavior was analyzed in [165]; data from the simulation were the prediction of farmers' debt, labor expenditures, desired labor expenditures, revenue from yield, subsidies to livestock, and total subsidies to land. A case study of women smallholder farmers in northern Vietnam was analyzed in [166], where CLD and SFD were used to capture critical variables of the quality of life of women small farmers. SD was used in the area of transforming food systems in the view of small-scale farmers; here CLD was used to capture the critical variables of the food system defined by farmers [167].

$\mathrm{SD}$ was used for evaluation of short-term and long-term decision trade-offs in the African farming industry [168]. Smallholder farms' management often face complex decision-making situations with conflicting objectives. The short-term improvement of the harvest can have a negative impact from a long-term perspective, and vice versa. The model showed that to achieve sustainability in food production, long-term objectives have to take precedence. Outputs of the simulation were the prediction of corn under several different scenarios up to the year 2047. Sjaifuddin et al. [169] analyzed food security behavior through environmental-based learning. SFD and CLD captured the main variables related to food security behavior. Outputs of the simulation were the prediction of food security behavior under several different scenarios.

\subsection{Health}

\subsubsection{Physical Diseases}

Various types of diseases are being investigated with the help of SD. For instance, a case study related to diabetes was located in Japan, where it provided predictions of the population with diabetes in that country and the population on dialysis due to diabetic nephropathy [170]. SD was used for analysis of hemodialysis patients with end-stage renal disease; outcomes of the simulation were the predicted hemoglobin level [171]. A case study from the United States shows a relation between overweight/obesity and socioeconomic status. Results of the simulation were represented by the prediction of the obese, overweight population in the US [172]. A socio-ecological view on overweight and obesity in children was described in [173], offering the prediction of the percentage of overweight and obesity. SD helped to investigate possibilities of taxes on sugar-sweetened beverages as childhood obesity prevention. Outputs of the simulation were predictions of the total weight reduced [174]. The issue of effective obesity prevention was studied by Jalali et al. [175]. The research was focused on the study of dynamics that regulate the adoption, implementation, and maintenance of intervention programs. The paper is novel in two respects: (a) it builds upon current public health intervention assessment methods; and (b) it formulates theories in strategy and organizational behavior to study the effectiveness of these interventions.

SD has also been applied for exploration of the outbreak of diseases and their association with key variables related to vaccination [176]. The outbreak of Ebola was analyzed by Powell, Mustafee, and Brown [177], who used CLD for capturing critical variables. Kianmehr et al. [178] focused on infection risk in the United States, using SFD to capture primal variables related to the spread and cure of infection. Van Ackere and Schulz [179] investigated cycles of vaccination decisions. Outputs of the simulation were represented by the prediction of infection, vaccination rate, and the fraction of susceptibility under four different scenarios for 80 years.

Cruz et al. [180] used SD to capture the dynamics of kidney transplantation in Colombia. The authors captured the main parts of kidney transplantation with CLD (e.g., kidney 
donation, waiting list, and diagnosis). The presented output of SFD was the number of patients on a waiting list, transplanted patients, patients in transplant, patients entering the waiting list, and patients in treatment up to the year 2045 under several different scenarios.

\subsubsection{Health Care and Related Areas}

There is quite an extensive list of topics that have been analyzed and investigated in the health-care domain. Topics range from intervention in the health system or hospitals [181,182] to clinical system transformation [183] and physician supply-demand and related return-to-work issues $[184,185]$.

The study of Farid et al. [186] focused on nurses' health and quality of care. A model based on SD was used to show the impact of nurses' workload. SFD captured the interaction between burnout risk factors, human effects, and system effects. Outputs of the simulation were the predication of fatigue, burnout, and absence for one week. The study concluded that long nurse shifts and work weeks doubled nursing fatigue level, while increasing burnout by up to six times, absenteeism by up to five times, and increased level of medical errors up to $150 \%$.

Implementation of SD models, ceteris paribus, to evaluate emergency care was presented in [187]. According to the authors, a SD approach offers significant advantages over more traditional modeling tools, as this approach can effectively incorporate dynamic and organizational complexity in today's heavily interconnected and interdependent healthcare systems.

Another issue in the health-care domain was studied by Morgan and Graber-Naidich [188]. Their work focused on a disproportionate concentration of general practitioners in urban areas of Canada. CLD captured the main variables related to rural and urban doctors, more specifically factors such as movement and competition between these areas. Outputs of the simulation were the prediction of the number of rural and urban doctors and rural and urban populations up to 2034.

The paper of Xiaotian Zhang et al. [189] focused on the impact of China's population policy on maternity insurance. Outputs of the simulation based on SD models were the prediction of a found balance of maternity insurance up to 2027 under several different scenarios. Results showed that an increase of the number of births (as a result of the two-child policy) can significantly affect the sustainability of insurance schemes.

\subsection{Miscellaneous}

In this section, examples of specific topics that cannot be unambiguously assigned to one of the three main domains are presented.

\subsection{1. $R \& D$ and Innovation}

Luna-Reyes et al. [190] proposed so-called group model building as a tool for interdisciplinary research. Simulation and SFD enables theory building by formalization of legitimate proposals. Participatory system modeling, where scientists from different fields of research contribute to the effort, leads to a synergic effect, and strengths of both qualitative and quantitative approaches help in the formulation of theoretical problems. Another study [191] focused on facilitation of a research effort using virtual communities as a shared platform for an exchange of ideas. SFD and CLD captured the main factors related to knowledge share. Outputs of the simulation were the prediction of the need for achievement, the need for affiliation, self-efficacy, information value, and instrumental value under several scenarios for 60 months. The issue of gender inequality in science was addressed in the paper of Lansu et al. [192]. CLD captured the main variables related to women's interest in science, using a concept of systemic gender knowledge. This knowledge has two main characteristics that make it systemic: (a) knowledge of gender inequality processes, and (b) analysis at the level of organization. Another study focused on restructuring of financial support projects for universities in Korea [193]. A model based on SD was used to analyze key factors influencing performance of these support 
projects. Results led to the conclusion that it is necessary to focus primarily on how the university intends to strengthen competitiveness in the mid- to long-term period, taking university specialization under consideration. Inducement of interest among academic staff members is crucial as well. Mendes and Aleluia [194] focused on aging in public policy making. SFD captured age groups of teachers and the flow of students. Outputs of the simulation presented the prediction of the number of students ranged by grades in basic school, the number of required teachers, and the number of hired teachers up to the year 2030. The possibility of teaching systems thinking to general education was presented in [195], where solar insulation was used as an example. SD was used to analyze the complexity of technology integration in secondary schools, where CLD was used to capture critical variables [196].

\subsubsection{Social Issues}

The impact of Facebook use on the quality of interpersonal communication was presented in [197]. SD has also been successfully applied in finding solutions for complex social problems. CLD was used to capture critical variables of smoking [198], quality of innovations, community health, and well-being [199] or social-ecological systems [200]. Incorporating social system dynamics in the Columbia river basin was done in [201], where CLD was used to capture key variables of the food-energy-water system. Ford and White [202] focused on prison rehabilitation programs. Outputs of the simulation were used for the prediction of the prison population, meaning the number of prisoners returning to prison over 105 months.

The behavior of rumor makers was analyzed in [203]. A rumor behavior evolution model based on SFD was developed to find patterns and laws of rumor makers' behavior to achieve rumor blocking. The results showed that negative attitude is a major factor in the occurrence of disinformation behavior, and improvement of the quality of life and reduction of social instability can prevent or significantly reduce negative rumor occurrence.

\subsubsection{Decision-Making}

Interpretation of studies dealing with decision-making is quite tricky, as all SD models are used for support of decision-making. However, there are papers focused on decisionmaking per se. For instance, evaluation of decision-making strategies in coping with forage and price was presented in [204]. A decision support system was created for biodiesel investors. Outcomes of the simulation enabled the prediction of the price of crude oil, crude palm oil stock, and crude palm oil price [205]. Integrated decision-making was presented for housing, energy, and well-being [206]. The decision support system was used for business innovations, and the results of the simulation were represented by the prediction of the number of customers and sales [207].

\subsubsection{Urban Issues}

Bao and He [208] used CLD and SFD to analyze urbanization development and water scarcity in a case study of Beijing, Tianjin, and Hebei. Outputs of the simulations enabled prediction of urbanization development and water supply under several different scenarios. Fang et al. [209] used SFD to test scenarios for sustainable development of urbanization in the same areas as the previous study. The output of the simulation was associated with the prediction of GDP, population, ecological land, and waste up to 2035. Li, Kou, and Wang [210] developed SFD and CLD that captured the dynamics of the life cycle of residential buildings. Outputs of the simulation were represented by the prediction of residential stock and energy consumption under four different scenarios up to 2025 . Li et al. [211] focused on urban sustainability in China. CLD captured the key social factors influencing urban adaptive capacity for sustainability. Liu et al. [212] focused on urban dynamics in the view of climate change. SFD captured temperature, urban population, and GDP. Outputs of the simulation enabled the prediction of urban land area under several scenarios up to 2050. Shrubsole et al. [213] focused on energy and environmental 
performance in buildings. CLD captured the relation between clients' and the industry's focus on energy and indoor environmental quality. Sing, Love, and Liu [214] investigated the rehabilitation of existing building stock. CLD captured urban rehabilitation in old private buildings. SFD focused on the influence of old private building stock. Outputs of the simulation were the prediction of several aged buildings under three different scenarios up to 2026. Moradi et al. [215] focused on impacts of virtual organization absorption on the quality of urban private constructions in Iran. SFD and CLD captured virtual organization and a quality compliance checking mechanism. Results suggested that the virtual organization absorption has positive impacts on the quality level of urban private constructions.

\subsection{Additional Group Analysis}

While analyzing published papers, one specific concern arose. From the methodological perspective, there are various types of tests that need to be or should be conducted. Models and their simulations have to be supported by verifications of their validity, robustness, and meaningfulness. Figure 4 provides a list of tests that were used for the model building and verification. Only papers that mentioned any type of test are included. Papers in which conducted tests were not presented or were not even conducted are excluded. The question is whether papers that do not provide methodological details should be published. Of course, models could have been appropriately built and tested, but without the methodological details appearing in the paper, future replication and reasonable model tuning are almost impossible. Sensitivity analysis is the most common method of testing, followed by structural analysis. The issue is that while structural analysis helps to verify a developed model, sensitivity analysis is used merely for analytical purposes without aiming to polish the model. The historical test and a real data test are separated because of separation in papers (fundamentally, these tests work based on the same principle). All these tests were conducted on models developed, in fact, predominantly using two software applications, Vensim and Stella (in various versions of these products). While the vast majority of models were associated with Vensim, other tools such as Powersim Studio, Anylogic, and Netlogo were used sporadically. These two findings are strongly interrelated, as some software applications provide a wide range of usable tests while others provide only a few.

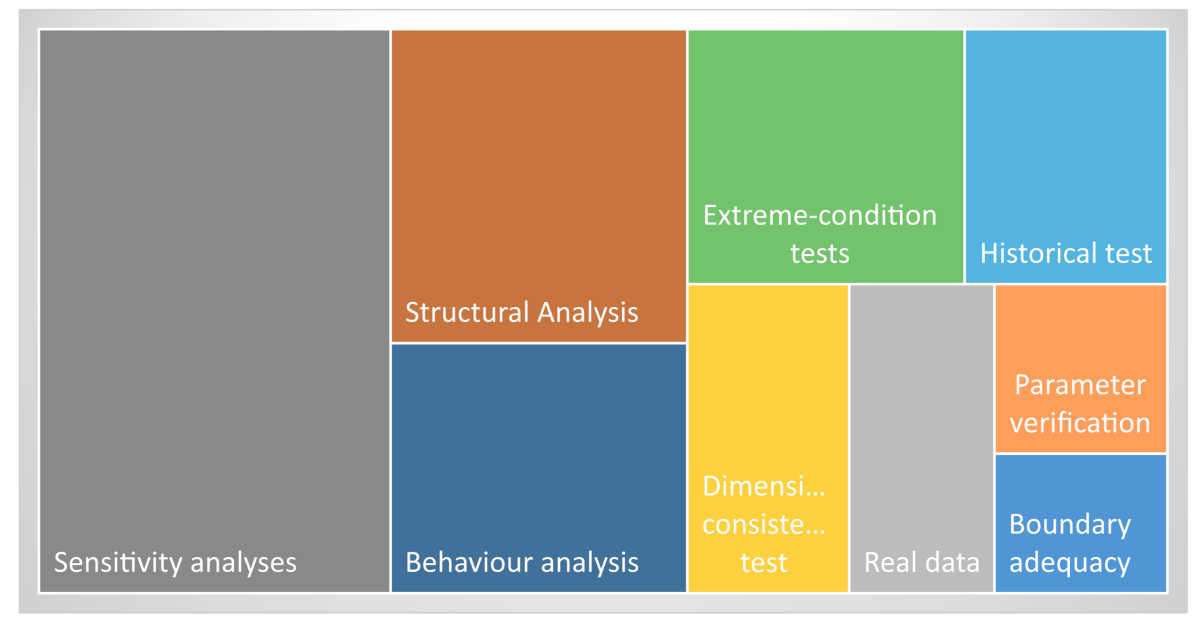

Figure 4. Tests conducted with the developed models.

Not surprisingly, in the studies under investigation, a vast majority of models were used for predictions. This would be fine if the aforementioned issue did not exist. Models cannot be verified, making the validity of predictions questionable. Usage of real data for model tuning is not a common procedure. One has to ask whether prediction is necessary and whether its absence would reduce the quality of papers. SD is used to improve 
understanding of systems and comprehending their dynamics. Some authors have taken CLD and SFD straightforwardly and applied them for future prediction without extensive analysis and insight into the system that SD methods enabled. Understanding of the system should come first, and modeling and future simulation can follow-not vice versa.

This approach can be implemented in the future. In addition to the main fields, which we presented in the previous section, several minor categories and subcategories can be identified. These topics can be considered as future research and application directions in the SD field. Minor topics also bring a better view on the interrelationships among three main disciplines and their subsections. In the business realm, topics related to product and production [216-218], organizational change [219], taxis and subsidies [220,221] or application of system archetypes [222,223] can be found.

Economics as a purely theoretical discipline closely related to the business domain has the potential to use SD in the exploration of green economics $[224,225]$ and co-evolutionary economic growth [226] or reformulation of classical models into the SD language [227]. Tourism represents one of the most frequently analyzed minor topics. Similar to economics, green alternatives and environmental solutions are being investigated [228-230]. Other topics are focused on social marketing [231,232] or start-up business. From the environmental perspective, the analysis of biofuel markets and sources can be elaborated $[233,234]$. The study of extreme nature conditions is mostly associated with specific research disciplines. However, SD can contribute to investigation of floods [235] or earthquakes [236]. Agriculture-related research can use SD for analysis of invasive alien plants [237]. Fishery is the last environmental topic with a potential to successfully use SD $[238,239]$. Healthrelated topics are quite rich, and their list is full of particular issues. Addiction represents one of them, and a focus on alcohol use [240,241] or cocaine addiction [242] can be beneficial for both medical research and SD methodology. Stress and depression represent a ubiquitous characteristic of the current lifestyle. SD has the potential to contribute to its research $[243,244]$.

There is another interesting finding. Topics analyzed and discussed in particular papers were strongly associated with China and partly with the United States. This corresponds with results of the next analysis in which we explored countries in which authors of papers were affiliated. Altogether, primary authors from 62 countries were included in the analysis, which indicates that SD as a methodological approach is being applied globally. The authors from the United States and China represented the first and second position respectively. However, China had a significantly higher connectivity in the conceptual network, which indicates that authors have emphasized this country in studies more intensively. The United Kingdom, Italy, Australia, India, Germany, the Netherlands, Taiwan, and Iran represented the rest of the top 10 countries where authors published papers with SD as a methodological tool used for modeling or simulation.

\section{Conclusions}

System dynamics is a widely used approach for modeling and simulation. Its main principles enable and support research in various disciplines. Its multidisciplinary nature has created a wide variety of topics that are rich enough to offer new ideas, highlight limitations, or provide analogies for further research. That is why we reviewed the existing literature and mapped the existing application domains. We identified 20 topics included in three main groups (Business, Environment, and Health Care). In the business group, we identified the following subgroups: Business performance, Resource management, Supply chain, Mineral markets, Market, Transport and traffic safety. In the Environment group, we identified the following subgroups: Pollution, Emissions and pollution, Sustainability, Water, Agriculture, Animals and fauna, Land use, and Farming. We identified the following subgroups in the Health Care group: Physical diseases, and Health care and related areas. Furthermore, we identified also other self-standing topics, such as R\&D and innovation, Social issues, Decision-making, and Urban issues. 
It has been shown that the possible range of topics and areas that can benefit from the application of SD methodology is already extensive, and it continues to broaden. It can be expected that the multidisciplinary nature of SD will be further emphasized in future research. SD partially overlaps with other modeling paradigms or can be used as a complement to other approaches. Modern trends emphasize the importance of competent decision-making, planning, efficient business processes, and sustainable production. The incorporation of SD tools has the potential to facilitate this effort and to enable better understanding of systems' functioning.

This review is associated with two principal limitations. First, it is not feasible to identify all relevant studies, as some papers may have been eliminated by the format of search queries. This limitation cannot be overcome due to the number of publications using the term "system dynamics" in titles, abstracts and keywords with different meanings. Second, we did not have access to all of the studies identified. In future replications or extensions of this study, additional steps may be conducted to obtain comprehensive pool of articles. Last, there are additional resources and repositories of papers that can be used. However, searching their content would increase redundancy in acquired papers rather than additional findings.

Author Contributions: Conceptualization, V.B.; data curation, M.Z.; funding acquisition, V.B.; methodology, M.Z. and V.B.; investigation, M.Z., V.B., and P.T.; validation, V.B. and P.T.; writing of original draft, M.Z., V.B., and P.T. All authors have read and agreed to the published version of the manuscript.

Funding: This research received no external funding.

Institutional Review Board Statement: Not applicable.

Informed Consent Statement: Not applicable.

Acknowledgments: The research has been partially supported by the Faculty of Informatics and Management, UHK, specific research project 2107 Integration of Departmental Research Activities and Students' Research Activities Support.

Conflicts of Interest: The authors declare no conflict of interest.

\section{References}

1. Williams, A.; Kennedy, S.; Philipp, F.; Whiteman, G. Systems Thinking: A Review of Sustainability Management Research. J. Clean. Prod. 2017, 148, 866-881. [CrossRef]

2. Lane, D.C. Should System Dynamics Be Described as a 'Hard' or 'Deterministic' Systems Approach? Syst. Res. Behav. Sci. 2000, 17, 3-22. [CrossRef]

3. Moher, D.; Liberati, A.; Tetzlaff, J.; Altman, D.G.; The PRISMA Group. Preferred Reporting Items for Systematic Reviews and Meta-Analyses: The PRISMA Statement. PLoS Med. 2009, 6, e1000097. [CrossRef]

4. Dong-Seok, K.; Chang-Kwon, C. Qualitative Simulation on the Dynamics between Social Capital and Business Performance in Strategic Networks. J. Distrib. Sci. 2016, 14, 31-45. [CrossRef]

5. Cosenz, F.; Noto, G. A Dynamic Business Modelling Approach to Design and Experiment New Business Venture Strategies. Long Range Plann. 2018, 51, 127-140. [CrossRef]

6. Aparicio, S.; Urbano, D.; Gómez, D. The Role of Innovative Entrepreneurship within Colombian Business Cycle Scenarios: A System Dynamics Approach. Futures 2016, 81, 130-147. [CrossRef]

7. Minato, N.; Morimoto, R. Dynamically Interdependent Business Model for Airline-Airport Coexistence. J. Air Transp. Manag. 2017, 64, 161-172. [CrossRef]

8. Yun, J.J.; Won, D.; Park, K.; Yang, J.; Zhao, X. Growth of a Platform Business Model as an Entrepreneurial Ecosystem and Its Effects on Regional Development. Eur. Plan. Stud. 2017, 25, 805-826. [CrossRef]

9. Yan, M.-R.; Tran-Danh, N.; Hong, L.-Y. Knowledge-Based Decision Support System for Improving e-Business Innovations and Dynamic Capability of IT Project Management. Knowl. Manag. Res. Pract. 2019, 17, 125-136. [CrossRef]

10. Rocha, H.; Kunc, M.; Audretsch, D.B. Clusters, Economic Performance, and Social Cohesion: A System Dynamics Approach. Reg. Stud. 2019, 1-14. [CrossRef]

11. Anjomshoae, A.; Hassan, A.; Kunz, N.; Wong, K.Y.; de Leeuw, S. Toward a Dynamic Balanced Scorecard Model for Humanitarian Relief Organizations' Performance Management. J. Humanit. Logist. Supply Chain Manag. 2017, 7, 194-218. [CrossRef]

12. Yu, H.; Dong, S.; Li, F. A System Dynamics Approach to Eco-Industry System Effects and Trends. Pol. J. Environ. Stud. 2019, 28, 1469-1482. [CrossRef] 
13. Mhatre, T.N.; Thakkar, J.J.; Maiti, J. Modelling Critical Risk Factors for Indian Construction Project Using Interpretive Ranking Process (IRP) and System Dynamics (SD). Int. J. Qual. Reliab. Manag. 2017, 34, 1451-1473. [CrossRef]

14. Wang, L.; Kunc, M.; Bai, S. Realizing Value from Project Implementation under Uncertainty: An Exploratory Study Using System Dynamics. Int. J. Proj. Manag. 2017, 35, 341-352. [CrossRef]

15. Van Oorschot, K.; Eling, K.; Langerak, F. Measuring the Knowns to Manage the Unknown: How to Choose the Gate Timing Strategy in NPD Projects: Measuring the Knowns to Manage the Unknown. J. Prod. Innov. Manag. 2018, 35, 164-183. [CrossRef]

16. Li, Y.; Jiang, L.; Taylor, T.R.B.; Ford, D.N. Impact of Labour Controls on Tipping Point Dynamics in Large Complex Projects: Impact of Project Labor Controls on Tipping Point Dynamics. Syst. Res. Behav. Sci. 2018, 35, 605-618. [CrossRef]

17. Pargar, F.; Kujala, J.; Aaltonen, K.; Ruutu, S. Value Creation Dynamics in a Project Alliance. Int. J. Proj. Manag. 2019, 37, 716-730. [CrossRef]

18. Wang, L.; Kunc, M.; Li, J. Project Portfolio Implementation under Uncertainty and Interdependencies: A Simulation Study of Behavioural Responses. J. Oper. Res. Soc. 2019, 1-11. [CrossRef]

19. Abbaspour, S.; Dabirian, S. Evaluation of Labor Hiring Policies in Construction Projects Performance Using System Dynamics. Int. J. Product. Perform. Manag. 2019, 69, 22-43. [CrossRef]

20. Lee, K.; Son, S.; Kim, D.K.; Kim, S. A Dynamic Simulation Model for Economic Feasibility of Apartment Development Projects. Int. J. Strateg. Prop. Manag. 2019, 23, 305-316. [CrossRef]

21. Chung, C.-H.; Angnakoon, P.; Li, J.; Allen, J. Virtual HRD and National Culture: An Information Processing Perspective. Eur. J. Train. Dev. 2016, 40, 21-35. [CrossRef]

22. Škraba, A.; Stanovov, V.; Semenkin, E.; Kofjač, D. Hybridization of Stochastic Local Search and Genetic Algorithm for Human Resource Planning Management. Organizacija 2016, 49, 42-54. [CrossRef]

23. Kunc, M.; O’Brien, F.A. Exploring the Development of a Methodology for Scenario Use: Combining Scenario and Resource Mapping Approaches. Technol. Forecast. Soc. Chang. 2017, 124, 150-159. [CrossRef]

24. Alizadeh-Zoeram, A.; Pooya, A.; Naji-Azimi, Z.; Vafaee-Najar, A. Simulation of Quality Death Spirals Based on Human Resources Dynamics. Inq. J. Health Care Organ. Provis. Financ. 2019, 56, 004695801983743. [CrossRef] [PubMed]

25. Xing, L.; Xue, M.; Hu, M. Dynamic Simulation and Assessment of the Coupling Coordination Degree of the Economy-ResourceEnvironment System: Case of Wuhan City in China. J. Environ. Manag. 2019, 230, 474-487. [CrossRef] [PubMed]

26. Wang, C.; Wood, L.C.; Abdul-Rahman, H.; Lee, Y.T. When Traditional Information Technology Project Managers Encounter the Cloud: Opportunities and Dilemmas in the Transition to Cloud Services. Int. J. Proj. Manag. 2016, 34, 371-388. [CrossRef]

27. Nair, P.R.; Anbuudayasankar, S.P. An Investigation on the Benefits of ICT Deployment in Supply Chain Management (SCM). Indian J. Sci. Technol. 2016, 9. [CrossRef]

28. Keilhacker, M.L.; Minner, S. Supply Chain Risk Management for Critical Commodities: A System Dynamics Model for the Case of the Rare Earth Elements. Resour. Conserv. Recycl. 2017, 125, 349-362. [CrossRef]

29. Cagliano, A.C.; De Marco, A.; Rafele, C. E-Grocery Supply Chain Management Enabled by Mobile Tools. Bus. Process Manag. J. 2017, 23, 47-70. [CrossRef]

30. Zhang, C. Small and Medium-Sized Enterprises Closed-Loop Supply Chain Finance Risk Based on Evolutionary Game Theory and System Dynamics. J. Shanghai Jiaotong Univ. Sci. 2016, 21, 355-364. [CrossRef]

31. Rawlins, J.M.; De Lange, W.J.; Fraser, G.C.G. An Ecosystem Service Value Chain Analysis Framework: A Conceptual Paper. Ecol. Econ. 2018, 147, 84-95. [CrossRef]

32. Choi, K. A System Perspective on Revenue Sharing in the Mobile Value Chain: An Evidence from China Mobile Video Ecosystem. Supply Chain Manag. Int. J. 2018, 23, 136-152. [CrossRef]

33. Armendáriz, V.; Armenia, S.; Atzori, A.S. Systemic Analysis of Food Supply and Distribution Systems in City-Region Systems-An Examination of FAO's Policy Guidelines towards Sustainable Agri-Food Systems. Agriculture 2016, 6, 65. [CrossRef]

34. Chang, W.-S.; Lin, Y.-T. The Effect of Lead-Time on Supply Chain Resilience Performance. Asia Pac. Manag. Rev. 2019, 24, 298-309. [CrossRef]

35. Olafsdottir, A.H.; Sverdrup, H.U. Defining a Conceptual Model for Market Mechanisms in Food Supply Chains, and Parameterizing Price Functions for Coffee, Wheat, Corn, Soybeans, and Beef. Int. J. Food Syst. Dyn. 2019, 10, 224-247. [CrossRef]

36. Bahadir, M.C.; Akdag, H.C. The System Dynamics Modelling for Container Capacity \& Transportation Planning Policies. Asian J. Shipp. Logist. 2019, 35, 200-212. [CrossRef]

37. Jin, H.-W. Analysis of Factors Affecting the Benefits of Demand Information Sharing. EM Ekon. Manag. 2019, 22, 204-219. [CrossRef]

38. Jeon, J.W.; Yeo, G.T. Study of the Optimal Timing of Container Ship Orders Considering the Uncertain Shipping Environment. Asian J. Shipp. Logist. 2017, 33, 85-93. [CrossRef]

39. Tong, W.; Mu, D.; Zhao, F.; Mendis, G.P.; Sutherland, J.W. The Impact of Cap-and-Trade Mechanism and Consumers' Environmental Preferences on a Retailer-Led Supply Chain. Resour. Conserv. Recycl. 2019, 142, 88-100. [CrossRef]

40. Choi, C.H.; Cao, J.; Zhao, F. System Dynamics Modeling of Indium Material Flows under Wide Deployment of Clean Energy Technologies. Resour. Conserv. Recycl. 2016, 114, 59-71. [CrossRef]

41. Sverdrup, H.U. Modelling Global Extraction, Supply, Price and Depletion of the Extractable Geological Resources with the LITHIUM Model. Resour. Conserv. Recycl. 2016, 114, 112-129. [CrossRef] 
42. Sverdrup, H.U.; Ragnarsdottir, K.V. A System Dynamics Model for Platinum Group Metal Supply, Market Price, Depletion of Extractable Amounts, Ore Grade, Recycling and Stocks-in-Use. Resour. Conserv. Recycl. 2016, 114, 130-152. [CrossRef]

43. Wang, D.; Nie, R.; Long, R.; Shi, R.; Zhao, Y. Scenario Prediction of China's Coal Production Capacity Based on System Dynamics Model. Resour. Conserv. Recycl. 2018, 129, 432-442. [CrossRef]

44. Arango-Aramburo, S.; Jaramillo, P.; Olaya, Y.; Smith, R.; Restrepo, O.J.; Saldarriaga-Isaza, A.; Arias-Gaviria, J.; Parra, J.F.; Larsen, E.R.; Gomez-Rios, L.M.; et al. Simulating Mining Policies in Developing Countries: The Case of Colombia. Socioecon. Plann. Sci. 2017, 60, 99-113. [CrossRef]

45. Liu, D.; Gao, X.; An, H.; Qi, Y.; Sun, X.; Wang, Z.; Chen, Z.; An, F.; Jia, N. Supply and Demand Response Trends of Lithium Resources Driven by the Demand of Emerging Renewable Energy Technologies in China. Resour. Conserv. Recycl. 2019, 145, 311-321. [CrossRef]

46. Hazra, T.; Samanta, B.; Dey, K. Real Option Valuation of an Indian Iron Ore Deposit through System Dynamics Model. Resour. Policy 2019, 60, 288-299. [CrossRef]

47. Sverdrup, H.U.; Olafsdottir, A.H.; Ragnarsdottir, K.V. On the Long-Term Sustainability of Copper, Zinc and Lead Supply, Using a System Dynamics Model. Resour. Conserv. Recycl. X 2019, 4, 100007. [CrossRef]

48. Zhang, X.; Geltner, D.; de Neufville, R. System Dynamics Modeling of Chinese Urban Housing Markets for Pedagogical and Policy Analysis Purposes. J. Real Estate Financ. Econ. 2018, 57, 476-501. [CrossRef]

49. Chung, B. System Dynamics Modelling and Simulation of the Malaysian Rice Value Chain: Effects of the Removal of Price Controls and an Import Monopoly on Rice Prices and Self-Sufficiency Levels in Malaysia: The Effects of Removing Price Controls and Import Monopoly. Syst. Res. Behav. Sci. 2018, 35, 248-264. [CrossRef]

50. Gonçalves, P. From Boom to Bust: An Operational Perspective of Demand Bubbles: P. Gonçalves: From Boom to Bust. Syst. Dyn. Rev. 2018, 34, 389-425. [CrossRef]

51. Wang, Y.; Zhang, F.; Zhang, Y.; Wang, X.; Fan, L.; Song, F.; Ma, Y.; Wang, S. Chinese Power-Grid Financial Capacity Based on Transmission and Distribution Tariff Policy: A System Dynamics Approach. Util. Policy 2019, 60, 100941. [CrossRef]

52. Wang, J.; Lai, J.-Y.; Chang, C.-H. Modeling and Analysis for Mobile Application Services: The Perspective of Mobile Network Operators. Technol. Forecast. Soc. Chang. 2016, 111, 146-163. [CrossRef]

53. Yun, J.J.; Won, D.; Park, K.; Jeong, E.; Zhao, X. The Role of a Business Model in Market Growth: The Difference between the Converted Industry and the Emerging Industry. Technol. Forecast. Soc. Chang. 2019, 146, 534-562. [CrossRef]

54. Pasaoglu, G.; Harrison, G.; Jones, L.; Hill, A.; Beaudet, A.; Thiel, C. A System Dynamics Based Market Agent Model Simulating Future Powertrain Technology Transition: Scenarios in the EU Light Duty Vehicle Road Transport Sector. Technol. Forecast. Soc. Chang. 2016, 104, 133-146. [CrossRef]

55. Azmi, M.; Tokai, A. Electric Vehicle and End-of-Life Vehicle Estimation in Malaysia 2040. Environ. Syst. Decis. 2017. [CrossRef]

56. Wen, L.; Bai, L. System Dynamics Modeling and Policy Simulation for Urban Traffic: A Case Study in Beijing. Environ. Model. Assess. 2017, 22, 363-378. [CrossRef]

57. Wang, H.; Zhang, K.; Chen, J.; Wang, Z.; Li, G.; Yang, Y. System Dynamics Model of Taxi Management in Metropolises: Economic and Environmental Implications for Beijing. J. Environ. Manag. 2018, 213, 555-565. [CrossRef]

58. Fontoura, W.B.; Chaves, G.L.D.; Ribeiro, G.M. The Brazilian Urban Mobility Policy: The Impact in São Paulo Transport System Using System Dynamics. Transp. Policy 2019, 73, 51-61. [CrossRef]

59. Kim, Y.; Lee, J.; Ahn, J. Innovation towards Sustainable Technologies: A Socio-Technical Perspective on Accelerating Transition to Aviation Biofuel. Technol. Forecast. Soc. Chang. 2019, 145, 317-329. [CrossRef]

60. Oliveira, G.D.; Roth, R.; Dias, L.C. Diffusion of Alternative Fuel Vehicles Considering Dynamic Preferences. Technol. Forecast. Soc. Chang. 2019, 147, 83-99. [CrossRef]

61. Jeon, J.W.; Wang, Y.; Yeo, G.T. Ship Safety Policy Recommendations for Korea: Application of System Dynamics. Asian J. Shipp. Logist. 2016, 32, 73-79. [CrossRef]

62. Estay-Ossandon, C.; Mena-Nieto, A. Modelling the Driving Forces of the Municipal Solid Waste Generation in Touristic Islands. A Case Study of the Balearic Islands (2000-2030). Waste Manag. 2018, 75, 70-81. [CrossRef]

63. Gutberlet, J.; Kain, J.-H.; Nyakinya, B.; Oloko, M.; Zapata, P.; Zapata Campos, M.J. Bridging Weak Links of Solid Waste Management in Informal Settlements. J. Environ. Dev. 2017, 26, 106-131. [CrossRef]

64. Phonphoton, N.; Pharino, C. A System Dynamics Modeling to Evaluate Flooding Impacts on Municipal Solid Waste Management Services. Waste Manag. 2019, 87, 525-536. [CrossRef]

65. Sukholthaman, P.; Sharp, A. A System Dynamics Model to Evaluate Effects of Source Separation of Municipal Solid Waste Management: A Case of Bangkok, Thailand. Waste Manag. 2016, 52, 50-61. [CrossRef] [PubMed]

66. Ardi, R.; Leisten, R. Assessing the Role of Informal Sector in WEEE Management Systems: A System Dynamics Approach. Waste Manag. 2016, 57, 3-16. [CrossRef]

67. Dasgupta, D.; Debsarkar, A.; Hazra, T.; Bala, B.K.; Gangopadhyay, A.; Chatterjee, D. Scenario of Future E-Waste Generation and Recycle-Reuse-Landfill-Based Disposal Pattern in India: A System Dynamics Approach. Environ. Dev. Sustain. 2017, 19, 1473-1487. [CrossRef]

68. Ghisolfi, V.; Diniz Chaves, G.L.; Ribeiro Siman, R.; Xavier, L.H. System Dynamics Applied to Closed Loop Supply Chains of Desktops and Laptops in Brazil: A Perspective for Social Inclusion of Waste Pickers. Waste Manag. 2017, 60, 14-31. [CrossRef] [PubMed] 
69. Breach, P.A.; Simonovic, S.P. Wastewater Treatment Energy Recovery Potential For Adaptation To Global Change: An Integrated Assessment. Environ. Manag. 2018, 61, 624-636. [CrossRef]

70. Nascimento, F.R.A.; Kiperstok, A.; Martín, J.; Morató, J.; Cohim, E. Decision Support System for Management of Reactive Nitrogen Flows in Wastewater System. Environ. Sci. Pollut. Res. 2018, 25, 8644-8653. [CrossRef]

71. Prouty, C.; Mohebbi, S.; Zhang, Q. Socio-Technical Strategies and Behavior Change to Increase the Adoption and Sustainability of Wastewater Resource Recovery Systems. Water Res. 2018, 137, 107-119. [CrossRef]

72. Rinsatitnon, N.; Dijaroen, W.; Limpiwun, T.; Suktavee, G.; Chinda, T. Reverse Logistics Implementation in the Construction Industry: Paper Waste Focus. J. Sci. Technol. 2018, 40, 798-805.

73. Sea-lim, K.; Plianpho, C.; Sukmake, P.; Pongcharoenkiat, W.; Chinda, T. Feasibility Study of Reverse Logistic of Steel Waste in the Construction Industry. Songklanakarin J. Sci. Technol. 2018, 40, 271-277.

74. Nedelciu, C.-E.; Ragnarsdóttir, K.V.; Stjernquist, I. From Waste to Resource: A Systems Dynamics and Stakeholder Analysis of Phosphorus Recycling from Municipal Wastewater in Europe. Ambio 2019, 48, 741-751. [CrossRef]

75. Chinda, T.; Engpanyalert, W.; Tananoo, A.; Chaikong, J.; Methawachananont, A. Dynamic Model for Construction and Demolition Waste Recycling in Bangkok, Thailand. Songklanakarin J. Sci. Technol. 2018, 40, 97-104.

76. Ding, Z.; Yi, G.; Tam, V.W.Y.; Huang, T. A System Dynamics-Based Environmental Performance Simulation of Construction Waste Reduction Management in China. Waste Manag. 2016, 51, 130-141. [CrossRef]

77. Sharma, N.; Vrat, P. Impact of Various Factors on Stock-Induced Food Waste in Indian Weddings: A System Dynamics Approach. J. Adv. Manag. Res. 2018, 15, 37-57. [CrossRef]

78. Treadwell, J.L.; Clark, O.G.; Bennett, E.M. Dynamic Simulation of Phosphorus Flows through Montreal's Food and Waste Systems. Resour. Conserv. Recycl. 2018, 131, 122-133. [CrossRef]

79. Xiao, B.; Niu, D.; Guo, X. Can China Achieve Its 2020 Carbon Intensity Target? A Scenario Analysis Based on System Dynamics Approach. Ecol. Indic. 2016, 71, 99-112. [CrossRef]

80. Liu, D.; Xiao, B. Can China Achieve Its Carbon Emission Peaking? A Scenario Analysis Based on STIRPAT and System Dynamics Model. Ecol. Indic. 2018, 93, 647-657. [CrossRef]

81. Zhang, L.; Jiang, Z.; Liu, R.; Tang, M.; Wu, F. Can China Achieve Its CO2 Emission Mitigation Target in 2030: A System Dynamics Perspective. Pol. J. Environ. Stud. 2018, 27, 2861-2871. [CrossRef]

82. Li, W.; Lu, C.; Ding, Y. A Systematic Simulating Assessment within Reach Greenhouse Gas Target by Reducing PM2.5 Concentrations in China. Pol. J. Environ. Stud. 2017, 26, 683-698. [CrossRef]

83. Freeman, R.; Yearworth, M.; Preist, C. Revisiting Jevons' Paradox with System Dynamics: Systemic Causes and Potential Cures: Revisiting Jevons' Paradox with System Dynamics. J. Ind. Ecol. 2016, 20,341-353. [CrossRef]

84. Scolozzi, R.; Geneletti, D. The Anthroposphere as an Anticipatory System: Open Questions on Steering the Climate. Sci. Total Environ. 2017, 579, 957-965. [CrossRef]

85. Navarro, A.; Tapiador, F.J. RUSEM: A Numerical Model for Policymaking and Climate Applications. Ecol. Econ. 2019, 165, 106403. [CrossRef]

86. Zhao, R.; Han, J.; Zhong, S.; Huang, Y. Interaction between Enterprises and Consumers in a Market of Carbon-Labeled Products: A Game Theoretical Analysis. Environ. Sci. Pollut. Res. 2018, 25, 1394-1404. [CrossRef] [PubMed]

87. Liu, Y.; Yang, D.; Xu, H. Factors Influencing Consumer Willingness to Pay for Low-Carbon Products: A Simulation Study in China: Consumer and Low Carbon Products. Bus. Strategy Environ. 2017, 26, 972-984. [CrossRef]

88. Scolozzi, R.; Schirpke, U.; Geneletti, D. Enhancing Ecosystem Services Management in Protected Areas Through Participatory System Dynamics Modelling. Landsc. Online 2019, 73, 1-17. [CrossRef]

89. Bixler, T.S.; Houle, J.; Ballestero, T.; Mo, W. A Dynamic Life Cycle Assessment of Green Infrastructures. Sci. Total Environ. 2019, 692, 1146-1154. [CrossRef]

90. Chiu, C.-C.; Château, P.-A.; Lin, H.-J.; Chang, Y.-C. Modeling the Impacts of Coastal Land Use Changes on Regional Carbon Balance in the Chiku Coastal Zone, Taiwan. Land Use Policy 2019, 87, 104079. [CrossRef]

91. Li, J.W. System Dynamic Analysis of Greenhouse Effect Based on Carbon Cycle and Prediction of Carbon Emissions. Appl. Ecol. Environ. Res. 2019, 17, 5067-5080. [CrossRef]

92. Li, T.; Liu, N.; Zhang, Q. System Dynamics Research on Economic Transformation and Environmentally Coordinated Development in China's Eastern Coastal Region. Pol. J. Environ. Stud. 2019, 28, 3569-3580. [CrossRef]

93. Matthew, G.Jr.; Nuttall, W.J.; Mestel, B.; Dooley, L.S. Low Carbon Futures: Confronting Electricity Challenges on Island Systems. Technol. Forecast. Soc. Chang. 2019, 147, 36-50. [CrossRef]

94. Cordier, M.; Uehara, T. How Much Innovation Is Needed to Protect the Ocean from Plastic Contamination? Sci. Total Environ. 2019, 670, 789-799. [CrossRef] [PubMed]

95. Dianati, K.; Zimmermann, N.; Milner, J.; Muindi, K.; Ezeh, A.; Chege, M.; Mberu, B.; Kyobutungi, C.; Fletcher, H.; Wilkinson, P.; et al. Household Air Pollution in Nairobi's Slums: A Long-Term Policy Evaluation Using Participatory System Dynamics. Sci. Total Environ. 2019, 660, 1108-1134. [CrossRef]

96. Tseng, C.-H.; Lee, I.-H.; Chen, Y.-C. Evaluation of Hexavalent Chromium Concentration in Water and Its Health Risk with a System Dynamics Model. Sci. Total Environ. 2019, 669, 103-111. [CrossRef]

97. da Silva, G.F.P.; Pegetti, A.L.; Piacesi, M.T.; Belderrain, M.C.N.; Bergiante, N.C.R. Dynamic Modeling of an Early Warning System for Natural Disasters. Syst. Res. Behav. Sci. 2019. [CrossRef] 
98. Ma, S.; Luo, Z.; Hu, S.; Chen, D. Promoting Information Technology for the Sustainable Development of the Phosphate Fertilizer Industry: A Case Study of Guizhou Province, China. R. Soc. Open Sci. 2018, 5, 181160. [CrossRef] [PubMed]

99. Fouseki, K.; Nicolau, M. Urban Heritage Dynamics in 'Heritage-Led Regeneration': Towards a Sustainable Lifestyles Approach. Hist. Environ. Policy Pract. 2018, 9, 229-248. [CrossRef]

100. Kotir, J.H.; Smith, C.; Brown, G.; Marshall, N.; Johnstone, R. A System Dynamics Simulation Model for Sustainable Water Resources Management and Agricultural Development in the Volta River Basin, Ghana. Sci. Total Environ. 2016, 573, 444-457. [CrossRef]

101. Iandolo, F.; Barile, S.; Armenia, S.; Carrubbo, L. A System Dynamics Perspective on a Viable Systems Approach Definition for Sustainable Value. Sustain. Sci. 2018, 13, 1245-1263. [CrossRef]

102. Liu, P.; Lin, B.; Wu, X.; Zhou, H. Bridging Energy Performance Gaps of Green Office Buildings via More Targeted Operations Management: A System Dynamics Approach. J. Environ. Manag. 2019, 238, 64-71. [CrossRef]

103. Ulli-Beer, S.; Kubli, M.; Zapata, J.; Wurzinger, M.; Musiolik, J.; Furrer, B. Participative Modelling of Socio-Technical Transitions: Why and How Should We Look Beyond the Case-Specific Energy Transition Challenge?: Participative Modelling of SocioTechnical Transitions. Syst. Res. Behav. Sci. 2017, 34, 469-488. [CrossRef]

104. Wang, X.; Zhang, J.; Ali, M.; Shahid, S.; He, R.; Xia, X.; Jiang, Z. Impact of Climate Change on Regional Irrigation Water Demand in Baojixia Irrigation District of China. Mitig. Adapt. Strateg. Glob. Chang. 2016, 21, 233-247. [CrossRef]

105. Baki, S.; Rozos, E.; Makropoulos, C. Designing Water Demand Management Schemes Using a Socio-Technical Modelling Approach. Sci. Total Environ. 2018, 622-623, 1590-1602. [CrossRef]

106. Qin, H.; Cai, X.; Zheng, C. Water Demand Predictions for Megacities: System Dynamics Modeling and Implications. Water Policy 2018, 20, 53-76. [CrossRef]

107. Garg, N.K.; Azad, S. Analysis of Cauvery Water-Sharing Award Using an Analytical Framework Model. J. Hydrol. 2019, 579, 124214. [CrossRef]

108. Hu, M.-C.; Fan, C.; Huang, T.; Wang, C.-F.; Chen, Y.-H. Urban Metabolic Analysis of a Food-Water-Energy System for Sustainable Resources Management. Int. J. Environ. Res. Public Health 2018, 16, 90. [CrossRef]

109. Huang, H.; Wang, J.; Han, Y.; Wang, L.; Li, X. Assessing Impacts of Water Regulations on Alleviating Regional Water Stress with a System Dynamics Model. Water Supply 2019, 19, 635-643. [CrossRef]

110. Jin, L.; Chang, Y.; Ju, X.; Xu, F. A Study on the Sustainable Development of Water, Energy, and Food in China. Int. J. Environ. Res. Public Health 2019, 16, 3688. [CrossRef] [PubMed]

111. Li, F.; Yu, D.; Zhao, Y.; Cao, R. Inter-Annual Change of the Drought Limit Water Level of a Reservoir Based on System Dynamics. Water Policy 2019, 21, 91-107. [CrossRef]

112. Mahdavi, T.; Bagheri, A.; Hosseini, S.A. Applying the System of Environmental and Economic Accounts for Water (SEEA-Water) for Integrated Assessment of Water Security in an Aquifer Scale-Case Study: Azarshahr Aquifer, Iran. Groundw. Sustain. Dev. 2019, 9, 100261. [CrossRef]

113. Su, Y.; Gao, W.; Guan, D. Integrated Assessment and Scenarios Simulation of Water Security System in Japan. Sci. Total Environ. 2019, 671, 1269-1281. [CrossRef]

114. Zare, F.; Elsawah, S.; Bagheri, A.; Nabavi, E.; Jakeman, A.J. Improved Integrated Water Resource Modelling by Combining DPSIR and System Dynamics Conceptual Modelling Techniques. J. Environ. Manag. 2019, 246, 27-41. [CrossRef]

115. Bester, R.; Blignaut, J.N.; Crookes, D.J. The Impact of Human Behaviour and Restoration on the Economic Lifespan of the Proposed Ntabelanga and Laleni Dams, South Africa: A System Dynamics Approach. Water Resour. Econ. 2019, $26,100126$. [CrossRef]

116. Cui, D.; Chen, X.; Xue, Y.; Li, R.; Zeng, W. An Integrated Approach to Investigate the Relationship of Coupling Coordination between Social Economy and Water Environment on Urban Scale-A Case Study of Kunming. J. Environ. Manag. 2019, 234, 189-199. [CrossRef]

117. Hosseinzadeh Ghazichaki, Z.; Monem, M.J. Development of Quantified Model for Application of Control Systems in Irrigation Networks by System Dynamic Approach. Irrig. Drain. 2019, 68, 433-442. [CrossRef]

118. Shahbazbegian, M.R.; Turton, A.; Mousavi Shafaee, S.M. Hydropolitical Self-Organization Theory; System Dynamics to Analyse Hydropolitics of Helmand Transboundary River. Water Policy 2016, 18, 1088-1119. [CrossRef]

119. Pagano, A.; Pluchinotta, I.; Pengal, P.; Cokan, B.; Giordano, R. Engaging Stakeholders in the Assessment of NBS Effectiveness in Flood Risk Reduction: A Participatory System Dynamics Model for Benefits and Co-Benefits Evaluation. Sci. Total Environ. 2019, 690, 543-555. [CrossRef]

120. Walters, J.P.; Archer, D.W.; Sassenrath, G.F.; Hendrickson, J.R.; Hanson, J.D.; Halloran, J.M.; Vadas, P.; Alarcon, V.J. Exploring Agricultural Production Systems and Their Fundamental Components with System Dynamics Modelling. Ecol. Model. 2016, 333, 51-65. [CrossRef]

121. Kumari, R.; Devadas, V. Modelling the Dynamics of Economic Development Driven by Agricultural Growth in Patna Region, India. J. Econ. Struct. 2017, 6. [CrossRef]

122. Rich, K.M.; Rich, M.; Dizyee, K. Participatory Systems Approaches for Urban and Peri-Urban Agriculture Planning: The Role of System Dynamics and Spatial Group Model Building. Agric. Syst. 2018, 160, 110-123. [CrossRef]

123. Ndhleve, S.; Obi, A.; Nakin, M.D.V. Public Spending on Agriculture and Poverty in Eastern Cape Province, South Africa. Afr. Stud. Q. 2017, 17, 23-46. 
124. Banson, K.E.; Nguyen, N.C.; Bosch, O.J.H. Using System Archetypes to Identify Drivers and Barriers for Sustainable Agriculture in Africa: A Case Study in Ghana: System Archetypes for African Agriculture. Syst. Res. Behav. Sci. 2016, 33, 79-99. [CrossRef]

125. Cheng, X.; Shuai, C.; Liu, J.; Wang, J.; Liu, Y.; Li, W.; Shuai, J. Modelling Environment and Poverty Factors for Sustainable Agriculture in the Three Gorges Reservoir Regions of China. Land Degrad. Dev. 2018, 29, 3940-3953. [CrossRef]

126. Kumar, J.L.G.; Zhao, Y.Q.; Hu, Y.S.; Babatunde, A.O.; Zhao, X.H. Nitrogen Dynamics Model for a Pilot Field-Scale Novel Dewatered Alum Sludge Cake-Based Constructed Wetland System. Environ. Technol. 2016, 36, 732-741. [CrossRef]

127. Matinzadeh, M.M.; Abedi Koupai, J.; Sadeghi-Lari, A.; Nozari, H.; Shayannejad, M. Development of an Innovative Integrated Model for the Simulation of Nitrogen Dynamics in Farmlands with Drainage Systems Using the System Dynamics Approach. Ecol. Model. 2017, 347, 11-28. [CrossRef]

128. Gao, W.; Hong, B.; Swaney, D.P.; Howarth, R.W.; Guo, H. A System Dynamics Model for Managing Regional N Inputs from Human Activities. Ecol. Model. 2016, 322, 82-91. [CrossRef]

129. Hosseinzadeh, Z.; Monem, M.J.; Nahavandi, N.; Tehrani, M.V. Development of a Conceptual Model for Application of HydroMechanical Gates in Irrigation Networks by a System Dynamic Approach: System Dynamic Conceptual Model for Automation of Irrigation Network. Irrig. Drain. 2017, 66, 808-819. [CrossRef]

130. Gunda, T.; Turner, B.L.; Tidwell, V.C. The Influential Role of Sociocultural Feedbacks on Community-Managed Irrigation System Behaviors During Times of Water Stress. Water Resour. Res. 2018, 54, 2697-2714. [CrossRef]

131. Mesgari, I. System Dynamics Modeling for National Agricultural System with Policy Recommendations: Application to Iran. Pak. J. Agric. Sci. 2017, 54, 457-466. [CrossRef]

132. Kuhmonen, T. Systems View of Future of Wicked Problems to Be Addressed by the Common Agricultural Policy. Land Use Policy 2018, 77, 683-695. [CrossRef]

133. Mokhtar, A.; Aram, S. Systemic Insights into Agricultural Groundwater Management: Case of Firuzabad Plain, Iran. Water Policy 2017, 19, 867-885. [CrossRef]

134. Jin, X.; Xu, X.; Xiang, X.; Bai, Q.; Zhou, Y. System-Dynamic Analysis on Socio-Economic Impacts of Land Consolidation in China. Habitat Int. 2016, 56, 166-175. [CrossRef]

135. Abdulla, I.; Arshad, F.M.; Bala, B.K.; Bach, N.L.; Mohammadi, S. Management of Beef Cattle Production in Malaysia: A Step Forward to Sustainability. Am. J. Appl. Sci. 2016, 13, 976-983. [CrossRef]

136. Dizyee, K.; Baker, D.; Rich, K.M. A Quantitative Value Chain Analysis of Policy Options for the Beef Sector in Botswana. Agric. Syst. 2017, 156, 13-24. [CrossRef]

137. Molina Benavides, R.A.; Sánchez- Guerrero, H.; Stanislao Atzori, A. A Conceptual Model to Describe Heat Stress in Dairy Cows from Actual to Questionable Loops. Acta Agronómica 2018, 67, 59-64. [CrossRef]

138. Dizyee, K.; Baker, D.; Omore, A. Upgrading the Smallholder Dairy Value Chain: A System Dynamics Ex-Ante Impact Assessment in Tanzania's Kilosa District. J. Dairy Res. 2019, 86, 440-449. [CrossRef]

139. Farrell, L.J.; Tozer, P.R.; Kenyon, P.R.; Ramilan, T.; Cranston, L.M. The Effect of Ewe Wastage in New Zealand Sheep and Beef Farms on Flock Productivity and Farm Profitability. Agric. Syst. 2019, 174, 125-132. [CrossRef]

140. Godde, C.; Dizyee, K.; Ash, A.; Thornton, P.; Sloat, L.; Roura, E.; Henderson, B.; Herrero, M. Climate Change and Variability Impacts on Grazing Herds: Insights from a System Dynamics Approach for Semi-arid Australian Rangelands. Glob. Chang. Biol. 2019, 25, 3091-3109. [CrossRef]

141. Neudert, R.; Salzer, A.; Allahverdiyeva, N.; Etzold, J.; Beckmann, V. Archetypes of Common Village Pasture Problems in the South Caucasus: Insights from Comparative Case Studies in Georgia and Azerbaijan. Ecol. Soc. 2019, 24. [CrossRef]

142. Tinsley, T.L.; Chumbley, S.; Mathis, C.; Machen, R.; Turner, B.L. Managing Cow Herd Dynamics in Environments of Limited Forage Productivity and Livestock Marketing Channels: An Application to Semi-Arid Pacific Island Beef Production Using System Dynamics. Agric. Syst. 2019, 173, 78-93. [CrossRef]

143. Lie, H.; Rich, K.M.; van der Hoek, R.; Dizyee, K. An Empirical Evaluation of Policy Options for Inclusive Dairy Value Chain Development in Nicaragua: A System Dynamics Approach. Agric. Syst. 2018, 164, 193-222. [CrossRef]

144. Wallentin, G.; Neuwirth, C. Dynamic Hybrid Modelling: Switching between AB and SD Designs of a Predator-Prey Model. Ecol. Model. 2017, 345, 165-175. [CrossRef]

145. Crookes, D.J. Does a Reduction in the Price of Rhino Horn Prevent Poaching? J. Nat. Conserv. 2017, 39, 73-82. [CrossRef]

146. Pérez, J.M.; Moreno, V.; Navas, J.; Vélez de Mendizábal, N.; Quesada, J.M.; Esteban, F.J. A System Dynamics Model of the Population Dynamics of Oestrus Sp. (Diptera: Oestridae) Infesting Iberian Ibex, Capra Pyrenaica. Ital. J. Zool. 2016, 83, 130-138. [CrossRef]

147. Phan, T.D.; Nguyen, N.C.; Bosch, O.J.H.; Nguyen, T.V.; Le, T.T.; Tran, H.T. A Systemic Approach to Understand the Conservation Status and Viability of the Critically Endangered Cat Ba Langur: Conservation Status of the Critically Endangered Cat Ba Langur. Syst. Res. Behav. Sci. 2016, 33, 742-752. [CrossRef]

148. Herrera, H. From Metaphor to Practice: Operationalizing the Analysis of Resilience Using System Dynamics Modelling: Operationalizing the Analysis of Resilience Using System Dynamics Modelling. Syst. Res. Behav. Sci. 2017, 34, 444-462. [CrossRef]

149. Rodríguez-Izquierdo, E.; Miquelajauregui, Y.; Padilla, P.; Bojórquez-Tapia, L.A. Modelling Approach for Crafting Environmental Regulations under Deep Uncertainty: Whale Watching in Ojo de Liebre, Mexico. Ecol. Model. 2019, 408, 108731. [CrossRef]

150. Liu, D.; Zheng, X.; Zhang, C.; Wang, H. A New Temporal-Spatial Dynamics Method of Simulating Land-Use Change. Ecol. Model. 2017, 350, 1-10. [CrossRef] 
151. Dang, A.N.; Kawasaki, A. Integrating Biophysical and Socio-Economic Factors for Land-Use and Land-Cover Change Projection in Agricultural Economic Regions. Ecol. Model. 2017, 344, 29-37. [CrossRef]

152. Sheng, X.; Cao, Y.; Zhou, W.; Zhang, H.; Song, L. Multiple Scenario Simulations of Land Use Changes and Countermeasures for Collaborative Development Mode in Chaobai River Region of Jing-Jin-Ji, China. Habitat Int. 2018, 82, 38-47. [CrossRef]

153. de Freitas, M.W.D.; Muñoz, P.; dos Santos, J.R.; Alves, D.S. Land Use and Cover Change Modelling and Scenarios in the Upper Uruguay Basin (Brazil). Ecol. Model. 2018, 384, 128-144. [CrossRef]

154. Park, G.; Park, H. Influence Analysis of Land Use by Population Growth on Urban Flood Risk Using System Dynamics; WIT Press: Naples, Italy, 2018; pp. 195-205.

155. Sanga, G.J.; Mungatana, E.D. Integrating Ecology and Economics in Understanding Responses in Securing Land-Use Externalities Internalization in Water Catchments. Ecol. Econ. 2016, 121, 28-39. [CrossRef]

156. Lim, C.L.; Prescott, G.W.; De Alban, J.D.T.; Ziegler, A.D.; Webb, E.L. Untangling the Proximate Causes and Underlying Drivers of Deforestation and Forest Degradation in Myanmar: Forest Degradation in Myanmar. Conserv. Biol. 2017, 31, 1362-1372. [CrossRef] [PubMed]

157. Yurike, Y.; Elmhirst, R.; Karimi, S.; Febriamans, R. Deforestation in Dharmasraya District, West Sumatra, Indonesia A Causal Loop Diagrams (CLD) Model. Asian J. Sci. Res. 2018, 11, 177-184. [CrossRef]

158. Nazir, N.; Ahmad, S. Forest Land Conversion Dynamics: A Case of Pakistan. Environ. Dev. Sustain. 2018, 20, 389-405. [CrossRef]

159. Forero Montaña, J.; Zimmerman, J.; Vakil, T.; Nelson, M.; Perez, M.; Medin, J. A Narrow Size Diameter Class Model for Tree Growth and Yield Simulation in a Mahoe (Talipariti Elatum (SW.) Fryxell, Malvaceae) Plantation in Puerto Rico. Ann. Silvic. Res. 2019, 43. [CrossRef]

160. Fuglestad, E.M.; Palmer, E. Land Ownership and Distribution: Modeling the Relationship to Property Law in the Norwegian Case. J. Rural. Stud. 2019, 72, 11-22. [CrossRef]

161. Tan, J.; Li, A.; Lei, G.; Xie, X. A SD-MaxEnt-CA Model for Simulating the Landscape Dynamic of Natural Ecosystem by Considering Socio-Economic and Natural Impacts. Ecol. Model. 2019, 410, 108783. [CrossRef]

162. Pande, S.; Savenije, H.H.G. A Sociohydrological Model for Smallholder Farmers in Maharashtra, India: Smallholder Sociohydrology. Water Resour. Res. 2016, 52, 1923-1947. [CrossRef]

163. Von Loeper, W.; Musango, J.; Brent, A.; Drimie, S. Analysing Challenges Facing Smallholder Farmers and Conservation Agriculture in South Africa: A System Dynamics Approach. S. Afr. J. Econ. Manag. Sci. 2016, 19, 747-773. [CrossRef]

164. Lie, H.; Rich, K.M. Modeling Dynamic Processes in Smallholder Dairy Value Chains in Nicaragua: A System Dynamics Approach. Int. J. Food Syst. Dyn. 2016, 7. [CrossRef]

165. Koláčková, G.; Krejčí, I.; Tichá, I. Dynamics of the Small Farmers' Behaviour-Scenario Simulations. Agric. Econ. Zemědělská Ekon. 2017, 63, 103-120. [CrossRef]

166. Ha, T.M.; Bosch, O.J.H.; Nguyen, N.C.; Trinh, C.T. System Dynamics Modelling for Defining Livelihood Strategies for Women Smallholder Farmers in Lowland and Upland Regions of Northern Vietnam: A Comparative Analysis. Agric. Syst. 2017, 150, 12-20. [CrossRef]

167. Kopainsky, B.; Hager, G.; Herrera, H.; Nyanga, P.H. Transforming Food Systems at Local Levels: Using Participatory System Dynamics in an Interactive Manner to Refine Small-Scale Farmers' Mental Models. Ecol. Model. 2017, 362, 101-110. [CrossRef]

168. Kopainsky, B.; Gerber, A.; Lara-Arango, D.; Nyanga, P.H. Short-Term versus Long-Term Decision Trade-Offs: Evidence from a Model-Based Observational Experiment with African Small-Scale Farmers. Syst. Res. Behav. Sci. 2019, 36, 215-228. [CrossRef]

169. Sjaifuddin, S.; Hidayat, S.; Fathurrohman, M.; Ardie, R.; Islami, R.A.Z.E. The Development of Food Security Behavior Model through Environmental-Based Learning: A System Dynamics Approach. J. Pendidik. IPA Indones. 2019, 8, 230-240. [CrossRef]

170. Sugiyama, T.; Goryoda, S.; Inoue, K.; Sugiyama-Ihana, N.; Nishi, N. Construction of a Simulation Model and Evaluation of the Effect of Potential Interventions on the Incidence of Diabetes and Initiation of Dialysis Due to Diabetic Nephropathy in Japan. BMC Health Serv. Res. 2017, 17. [CrossRef]

171. Rogers, J.; Gallaher, E.J.; Dingli, D. Personalized ESA Doses for Anemia Management in Hemodialysis Patients with End-Stage Renal Disease. Syst. Dyn. Rev. 2018, 34, 121-153. [CrossRef]

172. Chen, H.-J.; Xue, H.; Liu, S.; Huang, T.T.K.; Wang, Y.C.; Wang, Y. Obesity Trend in the United States and Economic Intervention Options to Change It: A Simulation Study Linking Ecological Epidemiology and System Dynamics Modeling. Public Health 2018, 161, 20-28. [CrossRef]

173. Carrete, L.; Arroyo, P.; Villaseñor, R. A Socioecological View toward an Understanding of How to Prevent Overweight in Children. J. Consum. Mark. 2017, 34, 156-168. [CrossRef]

174. Liu, S.; Osgood, N.; Gao, Q.; Xue, H.; Wang, Y. Systems Simulation Model for Assessing the Sustainability and Synergistic Impacts of Sugar-Sweetened Beverages Tax and Revenue Recycling on Childhood Obesity Prevention. J. Oper. Res. Soc. 2016, 67, 708-721. [CrossRef]

175. Jalali, M.S.; Rahmandad, H.; Bullock, S.L.; Lee-Kwan, S.H.; Gittelsohn, J.; Ammerman, A. Dynamics of Intervention Adoption, Implementation, and Maintenance inside Organizations: The Case of an Obesity Prevention Initiative. Soc. Sci. Med. 2019, 224, 67-76. [CrossRef]

176. Safarishahrbijari, A.; Teyhouee, A.; Waldner, C.; Liu, J.; Osgood, N.D. Predictive Accuracy of Particle Filtering in Dynamic Models Supporting Outbreak Projections. BMC Infect. Dis. 2017, 17. [CrossRef] 
177. Powell, J.H.; Mustafee, N.; Brown, C.S. The Rôle of Knowledge in System Risk Identification and Assessment: The 2014 Ebola Outbreak. J. Oper. Res. Soc. 2018, 69, 1286-1308. [CrossRef]

178. Kianmehr, H.; Sabounchi, N.S.; Sabounchi, S.S.; Cosler, L.E. A System Dynamics Model of Infection Risk, Expectations, and Perceptions on Antibiotic Prescribing in the United States. J. Eval. Clin. Pract. 2019. [CrossRef] [PubMed]

179. van Ackere, A.; Schulz, P.J. Explaining Vaccination Decisions: A System Dynamics Model of the Interaction between Epidemiological and Behavioural Factors. Socioecon. Plann. Sci. 2019, 100750. [CrossRef]

180. Cruz, J.P.; Guerrero Rueda, W.J.; Pérez, E.R.; Lizarazo Walteros, D.L.; Rico Ardila, P.C.; Castillo, A.M.; Torres Tinjacá, L.N. Kidney Procurement System in Colombia: A System Dynamics Approach. Gerenc. Políticas Salud 2019, 18, 1-26. [CrossRef]

181. Renmans, D.; Holvoet, N.; Criel, B. Combining Theory-Driven Evaluation and Causal Loop Diagramming for Opening the 'Black Box' of an Intervention in the Health Sector: A Case of Performance-Based Financing in Western Uganda. Int. J. Environ. Res. Public. Health 2017, 14, 1007. [CrossRef] [PubMed]

182. Hilmola, O.-P.; Henttu, V. Transportation Costs Do Matter: Simulation Study from Hospital Investment Decision. J. Model. Manag. 2016, 11, 560-584. [CrossRef]

183. Best, A.; Berland, A.; Herbert, C.; Bitz, J.; van Dijk, M.W.; Krause, C.; Cochrane, D.; Noel, K.; Marsden, J.; McKeown, S.; et al. Using Systems Thinking to Support Clinical System Transformation. J. Health Organ. Manag. 2016, 30, 302-323. [CrossRef] [PubMed]

184. Ishikawa, T.; Fujiwara, K.; Ohba, H.; Suzuki, T.; Ogasawara, K. Forecasting the Regional Distribution and Sufficiency of Physicians in Japan with a Coupled System Dynamics-Geographic Information System Model. Hum. Resour. Health 2017, 15, 64. [CrossRef] [PubMed]

185. Jetha, A.; Pransky, G.; Fish, J.; Hettinger, L.J. Return-to-Work Within a Complex and Dynamic Organizational Work Disability System. J. Occup. Rehabil. 2016, 26, 276-285. [CrossRef]

186. Farid, M.; Purdy, N.; Neumann, W.P. Using System Dynamics Modelling to Show the Effect of Nurse Workload on Nurses' Health and Quality of Care. Ergonomics 2019, 63, 952-964. [CrossRef] [PubMed]

187. McAvoy, S.; Staib, A.; Birch, S. Models of Evaluation under Ceteris Imparibus: System Dynamics and the Example of Emergency Care. Syst. Res. Behav. Sci. 2019. [CrossRef]

188. Morgan, J.S.; Graber-Naidich, A. Small System Dynamics Model for Alleviating the General Practitioners Rural Care Gap in Ontario, Canada. Socioecon. Plann. Sci. 2019, 66, 10-23. [CrossRef]

189. Zhang, X.; Zhou, L.; Antwi, H.A. The Impact of China's Latest Population Policy Changes on Maternity Insurance-a Case Study in Jiangsu Province. Int. J. Health Plann. Manag. 2019, 34, e617-e633. [CrossRef]

190. Luna-Reyes, L.F.; Black, L.J.; Ran, W.; Andersen, D.L.; Jarman, H.; Richardson, G.P.; Andersen, D.F. Modeling and Simulation as Boundary Objects to Facilitate Interdisciplinary Research: Modelling and Simulation for Interdisciplinary Research. Syst. Res. Behav. Sci. 2018. [CrossRef]

191. Wang, J.; Zhang, R.; Hao, J.-X.; Chen, X. Motivation Factors of Knowledge Collaboration in Virtual Communities of Practice: A Perspective from System Dynamics. J. Knowl. Manag. 2019, 23, 466-488. [CrossRef]

192. Lansu, M.; Bleijenbergh, I.; Benschop, Y. Seeing the System: Systemic Gender Knowledge to Support Transformational Change towards Gender Equality in Science. Gend. Work Organ. 2019, 26, 1589-1605. [CrossRef]

193. Lee, S.-Y. Development Strategies of Fiscal Programs for Universities in Korea-With Focused on Estimation of Effect of Restructuring of University Financial Support Project on University Competitiveness. Univers. J. Educ. Res. 2019, 7, 54-67. [CrossRef]

194. Mendes, J.P.; Aleluia, M. Aging Effects in Public Policy Making. Syst. Dyn. Rev. 2019, 35, 232-254. [CrossRef]

195. Mobus, G.E. Teaching Systems Thinking to General Education Students. Ecol. Model. 2018, 373, 13-21. [CrossRef]

196. Howard, S.K.; Thompson, K. Seeing the System: Dynamics and Complexity of Technology Integration in Secondary Schools. Educ. Inf. Technol. 2016, 21, 1877-1894. [CrossRef]

197. Davies, M.; Musango, J.K.; Brent, A.C. A Systems Approach to Understanding the Effect of Facebook Use on the Quality of Interpersonal Communication. Technol. Soc. 2016, 44, 55-65. [CrossRef]

198. Carvalho, H.C.; Mazzon, J.A.; Santos, J.R. A Tale of Complexity. J. Soc. Mark. 2018. [CrossRef]

199. Stringfellow, E.J. Applying Structural Systems Thinking to Frame Perspectives on Social Work Innovation. Res. Soc. Work Pract. 2017, 27, 154-162. [CrossRef]

200. Hossain, M.S.; Dearing, J.A.; Eigenbrod, F.; Johnson, F.A. Operationalizing Safe Operating Space for Regional Social-Ecological Systems. Sci. Total Environ. 2017, 584-585, 673-682. [CrossRef]

201. Givens, J.E.; Padowski, J.; Guzman, C.D.; Malek, K.; Witinok-Huber, R.; Cosens, B.; Briscoe, M.; Boll, J.; Adam, J. Incorporating Social System Dynamics in the Columbia River Basin: Food-Energy-Water Resilience and Sustainability Modeling in the Yakima River Basin. Front. Environ. Sci. 2018, 6. [CrossRef]

202. Ford, D.N.; White, R.J. Social Impact Bonds: The Goose and the Golden Eggs at Risk. Syst. Res. Behav. Sci. 2019. [CrossRef]

203. Zhu, X.; Liu, F. Research on Behavior Model of Rumor Maker Based on System Dynamics. Complexity 2017, 2017, 1-9. [CrossRef]

204. Ibáñez, J.; Martínez-Valderrama, J. Global Effectiveness of Group Decision-Making Strategies in Coping with Forage and Price Variabilities in Commercial Rangelands: A Modelling Assessment. J. Environ. Manag. 2018, 217, 531-541. [CrossRef] [PubMed]

205. Zabid, M.F.M.; Abidin, N.Z.; Applanaidu, S.D. MYPOBDEX: An Interactive Decision Support System for Palm-Based Biodiesel Investors. Int. J. Econ. Perspect. 2017, 11, 260-272. 
206. Macmillan, A.; Davies, M.; Shrubsole, C.; Luxford, N.; May, N.; Chiu, L.F.; Trutnevyte, E.; Bobrova, Y.; Chalabi, Z. Integrated Decision-Making about Housing, Energy and Wellbeing: A Qualitative System Dynamics Model. Environ. Health 2016, 15. [CrossRef]

207. Yan, M.-R. Improving Entrepreneurial Knowledge and Business Innovations by Simulation-Based Strategic Decision Support System. Knowl. Manag. Res. Pract. 2018, 16, 173-182. [CrossRef]

208. Bao, C.; He, D. Scenario Modeling of Urbanization Development and Water Scarcity Based on System Dynamics: A Case Study of Beijing-Tianjin-Hebei Urban Agglomeration, China. Int. J. Environ. Res. Public Health 2019, 16, 3834. [CrossRef] [PubMed]

209. Fang, C.; Cui, X.; Li, G.; Bao, C.; Wang, Z.; Ma, H.; Sun, S.; Liu, H.; Luo, K.; Ren, Y. Modeling Regional Sustainable Development Scenarios Using the Urbanization and Eco-Environment Coupler: Case Study of Beijing-Tianjin-Hebei Urban Agglomeration, China. Sci. Total Environ. 2019, 689, 820-830. [CrossRef]

210. Li, G.; Kou, C.; Wang, H. Estimating City-Level Energy Consumption of Residential Buildings: A Life-Cycle Dynamic Simulation Model. J. Environ. Manag. 2019, 240, 451-462. [CrossRef] [PubMed]

211. Li, Y.; Beeton, R.J.S.; Sigler, T.; Halog, A. Enhancing the Adaptive Capacity for Urban Sustainability: A Bottom-up Approach to Understanding the Urban Social System in China. J. Environ. Manag. 2019, 235, 51-61. [CrossRef]

212. Liu, Z.; Yang, Y.; He, C.; Tu, M. Climate Change Will Constrain the Rapid Urban Expansion in Drylands: A Scenario Analysis with the Zoned Land Use Scenario Dynamics-Urban Model. Sci. Total Environ. 2019, 651, 2772-2786. [CrossRef]

213. Shrubsole, C.; Hamilton, I.G.; Zimmermann, N.; Papachristos, G.; Broyd, T.; Burman, E.; Mumovic, D.; Zhu, Y.; Lin, B.; Davies, M. Bridging the Gap: The Need for a Systems Thinking Approach in Understanding and Addressing Energy and Environmental Performance in Buildings. Indoor Built Environ. 2019, 28, 100-117. [CrossRef]

214. Sing, M.C.P.; Love, P.E.D.; Liu, H.J. Rehabilitation of Existing Building Stock: A System Dynamics Model to Support Policy Development. Cities 2019, 87, 142-152. [CrossRef]

215. Moradi, H.; Sebt, M.H.; Shakeri, E. Evaluating the Impacts of Virtual Organization Absorption on the Quality of Urban Private Constructions; the System Dynamics Approach. Syst. Pract. Action Res. 2019, 32, 443-462. [CrossRef]

216. Brockhaus, S.; Fawcett, S.; Kersten, W.; Knemeyer, M. A Framework for Benchmarking Product Sustainability Efforts: Using Systems Dynamics to Achieve Supply Chain Alignment. Benchmarking Int. J. 2016, 23, 127-164. [CrossRef]

217. Onat, N.C.; Kucukvar, M.; Tatari, O.; Egilmez, G. Integration of System Dynamics Approach toward Deepening and Broadening the Life Cycle Sustainability Assessment Framework: A Case for Electric Vehicles. Int. J. Life Cycle Assess. 2016, 21, 1009-1034. [CrossRef]

218. Zou, B.; Guo, F.; Guo, J. Absorptive Capacity, Technological Innovation, and Product Life Cycle: A System Dynamics Model. SpringerPlus 2016, 5, 1662. [CrossRef] [PubMed]

219. Schweiger, S.; Stouten, H.; Bleijenbergh, I.L. A System Dynamics Model of Resistance to Organizational Change: The Role of Participatory Strategies. Syst. Res. Behav. Sci. 2018, 35, 658-674. [CrossRef]

220. Jia, S.; Yan, G.; Shen, A.; Zheng, J. A System Dynamics Model for Determining the Traffic Congestion Charges and Subsidies. Arab. J. Sci. Eng. 2017, 42, 5291-5304. [CrossRef]

221. Lu, C.; Liu, H.-C.; Tao, J.; Rong, K.; Hsieh, Y.-C. A Key Stakeholder-Based Financial Subsidy Stimulation for Chinese EV Industrialization: A System Dynamics Simulation. Technol. Forecast. Soc. Chang. 2017, 118, 1-14. [CrossRef]

222. Bureš, V.; Racz, F. Application of System Archetypes in Practice: An Underutilised Pathway to Better Managerial Performance. J. Bus. Econ. Manag. 2016, 17, 1081-1096. [CrossRef]

223. Bureš, V.; Rácz, F. Identification of Sustainability Key Factors Based on Capturing Dominant Feedbacks of Behavioural Stereotypes in Socio-Economic Systems. Systems 2017, 5, 42. [CrossRef]

224. Rudneva, L.; Pchelintseva, I.; Gureva, M. Scenario Modelling of the "Green” Economy in an Economic Space. Resources 2018, 7, 29. [CrossRef]

225. Uehara, T.; Nagase, Y.; Wakeland, W. Integrating Economics and System Dynamics Approaches for Modelling an EcologicalEconomic System. Syst. Res. Behav. Sci. 2016, 33, 515-531. [CrossRef]

226. Castellacci, F. Co-Evolutionary Growth: A System Dynamics Model. Econ. Model. 2018, 70, 272-287. [CrossRef]

227. Aliani, H.; Kafaky, S.B.; Monavari, S.M.; Dourani, K. Modeling and Prediction of Future Ecotourism Conditions Applying System Dynamics. Environ. Monit. Assess. 2018, 190, 729. [CrossRef]

228. Režný, L.; Bureš, V. Adding Feedbacks and Non-Linearity to the Neoclassical Growth Model: A New Realm for System Dynamics Applications. Systems 2018, 6, 8. [CrossRef]

229. Scholz, P.; Voracek, J. Organizational Culture and Green Management: Innovative Way Ahead in Hotel Industry. Meas. Bus. Excell. 2016, 20, 41-52. [CrossRef]

230. Widhianthini, W. A Dynamic Model for Sustainable Tourism Village Planning Based on Local Institutions. J. Reg. City Plan. 2017, 28, 1-15. [CrossRef]

231. Biroscak, B.J.; Bryant, C.; Khaliq, M.; Schneider, T.; Panzera, A.D.; Courtney, A.; Parvanta, C.; Hovmand, P. Using System Dynamics Modeling to Evaluate a Community-Based Social Marketing Framework: A Computer Simulation Study. J. Soc. Mark. 2019, 9, 53-76. [CrossRef]

232. Domegan, C.; McHugh, P.; Biroscak, B.J.; Bryant, C.; Calis, T. Non-Linear Causal Modelling in Social Marketing for Wicked Problems. J. Soc. Mark. 2017, 7, 305-329. [CrossRef] 
233. Jadun, P.; Vimmerstedt, L.J.; Bush, B.W.; Inman, D.; Peterson, S. Application of a Variance-Based Sensitivity Analysis Method to the Biomass Scenario Learning Model. Syst. Dyn. Rev. 2017, 33, 311-335. [CrossRef]

234. Mudavanhu, S.; Blignaut, J.; Nkambule, N.; Morokong, T.; Vundla, T. A Cost-Benefit Analysis of Using Rooikrans as Biomass Feedstock for Electricity Generation: A Case Study of the De Hoop Nature Reserve, South Africa. S. Afr. J. Econ. Manag. Sci. 2016, 19, 788-813. [CrossRef]

235. Berariu, R.; Fikar, C.; Gronalt, M.; Hirsch, P. Resource Deployment under Consideration of Conflicting Needs in Times of River Floods. Disaster Prev. Manag. Int. J. 2016, 25, 649-663. [CrossRef]

236. Xu, J.; Rao, R.; Dai, J. Risk Perception-Based Post-Seismic Relief Supply Allocation in the Longmen Shan Fault Area: Case Study of the 2013 Lushan Earthquake. Hum. Ecol. Risk Assess. Int. J. 2016, 22, 825-844. [CrossRef]

237. Nkambule, N.P.; Blignaut, J.N.; Vundla, T.; Morokong, T.; Mudavanhu, S. The Benefits and Costs of Clearing Invasive Alien Plants in Northern Zululand, South Africa. Ecosyst. Serv. 2017, 27, 203-223. [CrossRef]

238. Inomata, S.O.; Gonzalez, A.M.G.O.; Román, R.M.S.; de Souza, L.A.; de Carvalho Freitas, C.E. Sustainability of Small-Scale Fisheries in the Middle Negro River (Amazonas-Brazil): A Model with Operational and Biological Variables. Ecol. Model. 2018, 368, 312-320. [CrossRef]

239. Rammelt, C.F.; van Schie, M. Ecology and Equity in Global Fisheries: Modelling Policy Options Using Theoretical Distributions. Ecol. Model. 2016, 337, 107-122. [CrossRef]

240. Apostolopoulos, Y.; Lemke, M.K.; Barry, A.E.; Lich, K.H. Moving Alcohol Prevention Research Forward-Part II: New Directions Grounded in Community-Based System Dynamics Modeling: System Dynamics Modeling in Alcohol Prevention. Addiction 2018, 113, 363-371. [CrossRef]

241. Clapp, J.D.; Madden, D.R.; Villasanti, H.G.; Giraldo, L.F.; Passino, K.M.; Reed, M.B.; Puentes, I.F. A System Dynamic Model of Drinking Events: Multi-Level Ecological Approach. Syst. Res. Behav. Sci. 2018, 35, 265-281. [CrossRef]

242. Arantes do Amaral, J.A.; Hess, A. The Dynamics of Providing Support to Crack Cocaine Addicts in Open-Air Drug Scenes: The Lessons Learned by the 'Helpers' Intervention Project. Int. J. Action Res. 2018, 14, 30-51. [CrossRef]

243. Matchar, D.B.; Ansah, J.P.; Koh, V.; Whitson, H.E. Trajectories of Functional Ability over the Life Course: A Conceptual Model of the Interaction of Stressor-Induced Functional Loss and Resilience. Syst. Dyn. Rev. 2018, 34, 481-502. [CrossRef] [PubMed]

244. Wittenborn, A.K.; Rahmandad, H.; Rick, J.; Hosseinichimeh, N. Depression as a Systemic Syndrome: Mapping the Feedback Loops of Major Depressive Disorder. Psychol. Med. 2016, 46, 551-562. [CrossRef] [PubMed] 